\title{
Chronology and development of the Chalcolithic necropolis of Varna I
}

\author{
Raiko Krauß 1, Clemens Schmid 2, David Kirschenheuter 1, Jonas Abele 1, \\ Vladimir Slavchev 3 and Bernhard Weninger 4 \\ 1 Institute for Early and Prehistory and Medieval Archaeology, Tübingen University, Tübingen, DE \\ raiko.krauss@uni-tuebingen.de \\ 2 Institute of Pre- and Protohistoric Archaeology, Kiel University, Kiel, DE \\ 3 Regional Historical Museum Varna, Varna, BG \\ 4 Institute for Early and Prehistory, Köln University, Köln, DE
}

\begin{abstract}
In the following paper, we present the main results of our now completed studies of the Varna I cemetery, based on the excavations undertaken by Ivan Ivanov in the years 1972-1991. The richness of the assemblages is singular in Old World prehistory. To tackle the question of its internal, chronological development, we applied correspondence analysis (CA) to a newly created database that includes the inventories of all presently known graves, symbolic burials and find deposits. The rank order of the seriated inventories was used to establish a CA-based ${ }^{14} \mathrm{C}$-age model for wiggle matching. In combination with topographic observations and social network analysis (SNA), our studies provide a new understanding both of the chronological and spatial distribution of the graves and burial goods, as well as new insights into the social structure, gender roles, individual relationships and ritual practices of the Chalcolithic community.
\end{abstract}

KEY WORDS - Varna cemetery; radiocarbon dating; correspondence analysis; social network analysis; Chalcolithic

\section{Kronologija in razvoj bakrenodobne nekropole Varna I}

IZVLEČEK - V članku predstavljamo glavne rezultate zaključenih študij grobišča Varna I, ki temeljijo na izkopavanjih Ivana Ivanova. Ta so potekala v letih 1972-1991. Bogastvo najdb je edinstveno $v$ svetovni prazgodovini. Pri analizi podatkov, ki vključujejo inventar vseh trenutno znanih grobnih celot, simboličnih pokopov in drugih najdb smo uporabili korespondenčno analizo (CA), s pomočjo katere smo ugotavljali notranji kronološki razvoj na grobišču. Uporabili smo vrstni red zbirov $v$ seriaciji, da bi s pomočjo "wiggle matching "metode vapostavili radiokarbonski model, ki temelji na korespondenčni analizi. Naša študija nudi nove razlage tako kronološke kot prostorske razporeditve grobov in grobnih pridatkov na podlagi združevanja topografije in analize socialnih omrežij (SNA), kar vodi tudi v nova spoznanja o družbeni strukturi, vlogi spolov, individualnih odnosih in ritualnih praksah $v$ tej bakrenodobni skupnosti.

KLJUČNE BESEDE - grobišče Varna; radiokarbonsko datiranje; korespondenčna analiza; analiza socialnih omrežij; bakrena doba 


\section{Introduction}

To begin, we would like to mention that a longer paper with a more complete presentation of the applied methods and investigations as well as the complete master-database has been submitted for publication to the Eurasia-Department of the German Archaeological Institute $\mathbf{1}$, whereby the additional data obtained and the results will be printed in combination with a complete catalogue of all the excavated Varna graves. While awaiting this later publication of the cemetery, we are extremely grateful to Mihael Budja and his editorial team for the chance to present and discuss some of our most important results already here. We chose to focus on the internal chronological development of the burial site. To this end, in the following, we describe the two main chronological components of the Varna cemetery, namely - first - the archaeological contents and statistical properties of the correspondence analysis (CA), and - second - the absolute age-calibration of the CA, which is now based on a large number of radiocarbon dates (filtered: $\mathrm{N}=38$; unfiltered: $\mathrm{N}=78$ ). All other aspects, such as the role of gender and age, social inequality as well as kinship, have been dealt with previously. Hence, in the present context, these facts will be considered to some limited extent only. The focus here is on aspects which we consider relevant to the chronology of the burial ground.

\section{Overview of the approach taken}

In brief, our approach will be as follows. By including the graves of the Varna II cemetery in the CAanalysis of Varna I, we create clear evidence for the chronological validity of the CA. With the application of social network analysis (SNA), we undertake studies that are focused on unravelling the strongly coherent network between the graves, a circumstance that demonstrates the profound community character of the Varna cemetery. The SNA is of particular use in understanding the unique position of Grave 43 on the CA-curve. Essentially, its position is due to the many close connections with the similarly furnished Graves 1, 3, 4, 15, and 97, all of which date to the younger end of the CA. In parallel to some few conservative elements that are operating next to the generally high degree of connection, Grave 43 displays a broad cross-section of the grave goods found in funerary rituals. The specific proximity of Grave 43 to certain older graves is most likely social- ly connoted, and allows us to reconstruct the persisting memory of a traditional funeral ritual. Finally, we describe the two main chronological components of the Varna cemetery: (1) the archaeological contents and statistical properties of the CA, and (2) the absolute age-calibration of the CA. Based on a large number of seriated ${ }^{14} \mathrm{C}$-ages, the cemetery begins at $4590 \mathrm{cal} \mathrm{BC}$ and ends at $4340 \mathrm{cal} \mathrm{BC}$. Due to the methodology applied, we achieved a precise dating for all the graves included in the CA, whether directly ${ }^{14} \mathrm{C}$-dated, or not. The period of $\sim 250$ years for the cemetery, when compared with the overall sum of 270 burials, provides us with guidelines as to the role of the Varna burial ground in its wider historical-cultural context: The proportion of burials in comparison with the large number of symbolic burials indicates that Varna I quite probably contains the burials of individuals from different settlements. We should therefore perceive Varna I as a prominent burial site within the larger settlement area of the Kodžadermen-Gumelniţa-Karanovo VI Complex, and which will certainly encompass the known tell settlements in the hinterland of the western coast of the Black Sea.

\section{Statistical analysis}

The cemetery master-database is a simply structured table containing 316 rows which represent the complete set of individual burial contexts (in a wider sense: mainly burials, but also including symbolic graves, and material deposits) of the Varna necropolis, and 193 columns, which contain the entire set of attributes associated with the burial contexts (for example: site-coordinates, dimensions of the grave pit, manner of burial or deposit, burial goods etc.). This cemetery master-database was constructed at the Eberhard Karls University of Tübingen in the course of two seminars on statistical methods in the years 2012 and 2013. Additional classification of the individual grave goods is due to the (still now to some extent) preliminary work of several colleagues. At this point, we would like to emphasise the altogether quite profound extent of the Varna project, which covers (and still now involves) the support of, and explicit data entry by, many different experts. In brief, the analysis of the copper tools, weapons and jewellery is in the hands of Kalin Dimitrov (Sofia) taking advantage of older results (Todorova 1981; Dimitrov 2002). The anthropological data is provided by Steve Zäuner (Tübingen). Verena Leusch

1 R. Krauß, J. Abele, D. Kirschenheuter, C. Schmid and B. Weninger. Statistische Auswertung und interne Chronologie der kupferzeitlichen Bestattungen aus Varna I. Submitted in September 2016. 
(Mannheim) has developed a new typology of the gold objects based on the existing classification undertaken by Henrieta Todorova and Ivan Vajsov (2001). For the stone tools and weapons, as well as for the ceramic vessels, we developed our own classification. Based on all the available information, as presently stored within the master-database, but which is even now being extended to enable stepwise publication of successive Varna volumes, a wide range of studies has been possible from fields such as artefact description, bi- and multivariate analysis of the find contexts; definition, visualisation and mapping of the different cemetery phases etc. In the present article, we put focus on the results of CA and SNA, and their implications for the relative chronology of the cemetery. We also note that, although an earlier published CA of all graves and attributes displayed a rather indifferent statistical distribution of the graves and their inventories (Krauß et al. 2014), in the meantime we recognised that a determined and systematical data reduction (both in terms of graves and variables) allowed us to significantly enhance both the archaeological comprehensibility of the seriation, as well as the achieved temporal resolution. Before continuing, we comment briefly on some of the underlying (general) properties of the Varna cemetery as seen from the perspective of the present master-database.

One of the main factors influencing the database is the highly unequal distribution of the objects among the graves. For example, when examining only gold objects, already one third of all finds originate from the particularly richly furnished Grave 43, and a further third are divided between the rich symbolic graves and deposits 1, 4, 36, 41, and 63a. In addition to the gold objects, stone beads and jewellery made from mussel and snail shells are also extremely unevenly distributed among the graves. What complicates matters, if only from the chronological perspective, is that such differences in furnishing primarily reflect social aspects, whereby such ritual practices contribute little to the targeted chronological order of the graves. On these grounds, when approaching the chronological dimension, we found it useful to work with a carefully binarised data set, which uses only presence-absence relationships. Note that this applies only to the multivariate statistical analyses, not to the contents of the master database itself. With this approach, but as we learnt only after many experiments, even applying a limited amount of data filtering was sufficient to achieve the target- ed 'ideal' shape for the CA, in which the factor-scores for the database-rows (graves, symbolic burials, deposits) and for the columns (attributes) are arranged along a parabola-shaped regression curve (Fig. 1 and Tab. 1). During the experiments that finally led us to establish this (altogether quite satisfactory) result, filtering was executed manually by implementing archaeological considerations with respect to the significance of the individual grave goods under study 2 . Looking critically at the achieved CA, we note that the applied manual optimisation method of 'selective sampling without later replacement' may have introduced some unrequested bias (towards certain grave goods, and away from others), but which was unavoidable due to the huge amount of possible permutations. In this respect, the CA results may be improved in the future by applying some kind of automated outlier analysis. For the moment, we are satisfied that the CA achieved thus far is a step forward in comparison to our initial seriation attempts (Krauß et al. 2014).

The next (immediately following) question is now, of course, which end of the CA represents the earliest burials and which are the latest? Assuredly, the wrong way to answer this question is to look at the available ${ }^{14} \mathrm{C}$-dates, but this may not be immediately obvious to all readers. We will return to this question below. As a perhaps more viable alternative, we have applied an easy-to-install archaeological method, which is to include in the CA the three graves from Varna II, which count as the predecessors of Varna I (Ivanov 1978), and have a quick look at which end of factor 1 the corresponding CA-scores come to lie (Fig. 2). Naturally, the results remain to be independently confirmed. Most striking are the numerous grave goods from Grave 3 (Varna II 3), which, in addition to pottery, contains vessels, stone tools and an antler pick, various items of jewellery from various minerals, spondylus, and dentalium, as well as metal objects, namely a copper armlet, a copper finger ring, and 31 beads of convoluted gold plate. The pottery vessels from Varna II are clearly typologically earlier than those from Varna I. A single carbon date from a red deer tooth from Grave 1 (Varna II 1) independently confirms this (OxA-X2414-52: 5934 \pm 33 BP). Within the CA, Graves 1 and 3 from Varna II lie close to each other at the same end of the curve. On the basis of their inventory, they can be placed in Phase IV of the Hamangia and Sava culture. But what does it mean that the two graves can be included in the CA of Varna I? The link

2 In this way, 59 artefacts and 33 graves were removed from the analysis step by step. 
results mainly from the copper and spondylus jewellery, as well as an antler hoe and the stone adzes, hence grave goods which mostly disappear in the later phases of Varna I. They do not, however, give any information about the real age of these finds, but merely confirm that the CA begins at this end with the earliest graves. On account of its scanty burial goods, Grave 2 from Varna II anyway could only be passively included in the $\mathrm{CA}$, and hence it remains meaningless regarding questions of chronology. Mo-

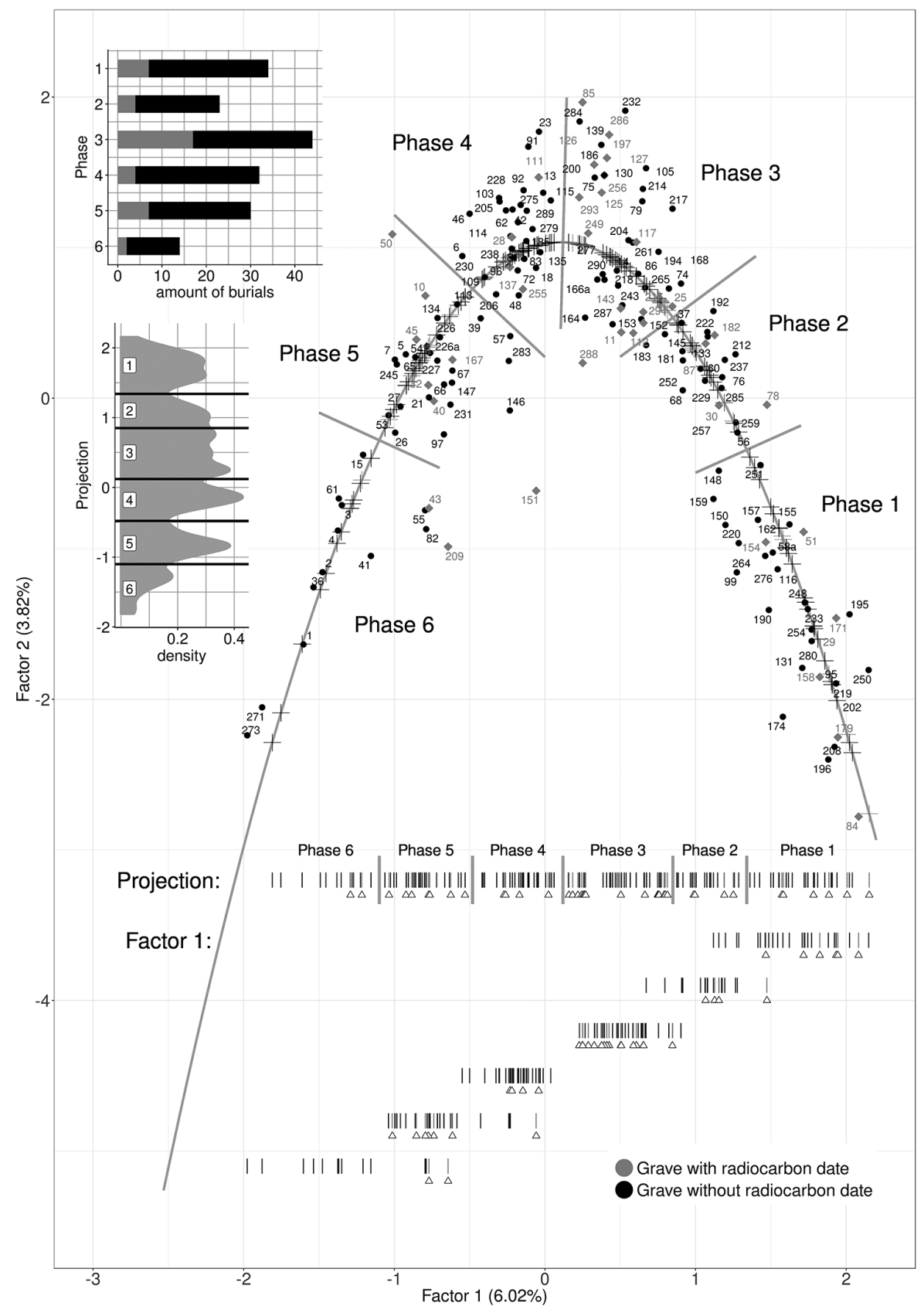

Fig. 1. Varna I. CA-results based on the filtered data-subset of graves $(N=177)$ and artefacts $(N=80)$, with $13{ }^{14} \mathrm{C}$-dated graves added to the initial selection. Main graph: the CA point cloud is approximated by a parabolic regression curve, with six visually defined phases shown by their borderlines set perpendicular to the parabola. Cross symbols on the curve represent the exact scaling positions of perpendicularly shifted - 'projected' - grave points. Lower: a comparison of the two barcode plots Clabelled 'Projection' and 'Factor 1') illustrates the enhanced phase-separation achieved by projecting grave scores onto the parabola. Their vertical projection onto Factor 1 is associated with increased phase-overlap. The small white triangles indicate graves with radiocarbon dates. Top Left: the stacked bar chart displays the number of graves per phase with and without radiocarbon dates (grey $={ }_{14} \mathrm{C}$-dated graves; black = undated). The density plot below shows the date distribution along the $x$-axis obtained via projection (standard deviation of the smoothing kernel =0.1). 
reover, the sequence obtained for the Varna I cemetery shows a sensible development of the ceramic vessel shapes (see below). Indeed, in the case of the specific stands and profiled pots, the development corresponds in detail to that known from tell settlements in the region.

The arrangement of the graves and their inventories shows a linear succession along the CA, which is most likely due to the equally linear sequence of the graves themselves. A bipolar interpretation of the grave succession, for example male-female, is equally unlikely and can actually be excluded altogether, due to the known CA location of many of the anthropologically determined burials. Similarly, the different anthropologically determined age groups are also spread quite evenly over the CA. Furthermore, if the CA shape were mainly due to social differences (e.g., quality or choice of the burial goods), then we would expect the observed linear structure only under the condition that the differences between the poorest and richest burials were similarly graduated. In this case, the richest graves would have been grouped in one part of the CA curve and the poor ones in an opposite part, with the area in between showing a tendency from 'rich' to 'poor'. But such bi-polar distinction is clearly not the case: even if one end of the CA does indeed show some exceptionally rich tombs, especially many symbolic tombs, the rich graves occur in all sections of the CA, and the poorer graves are also spread relatively evenly over the curve. A potential CA-bias due to family relationships is also ruled out, since what we observe is a continuous spread of the graves and their inven-

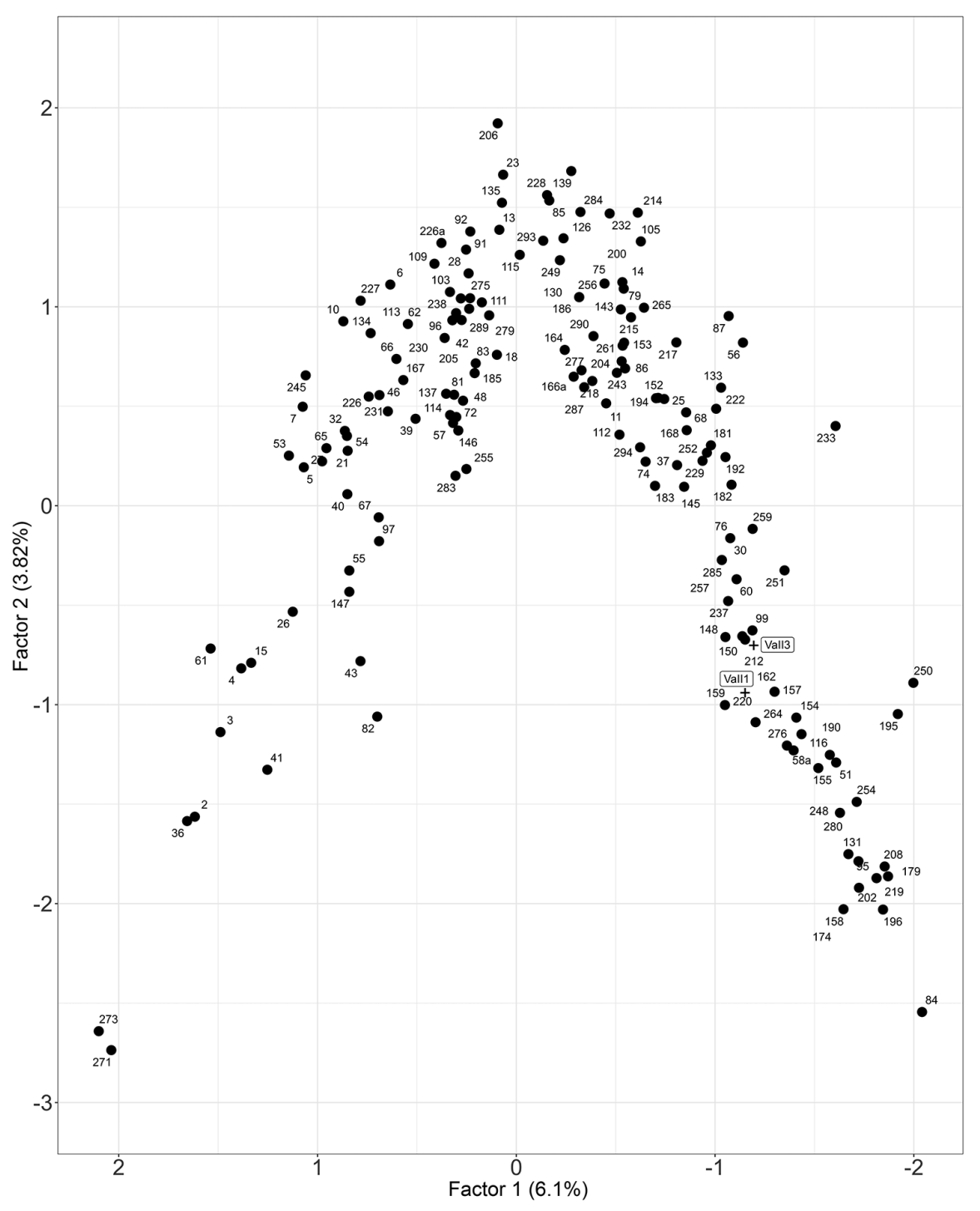

Fig. 2. Varna I and Varna II. CA based on the filtered data-subset (as in Figure 1 but without the 13 additional graves), with two graves from Varna II added in order to identify the older and younger ends of the CA. The Varna II graves are numbered 1 and 3. Result: knowing that Varna II is older than Varna I, the chronological order represented by the CA plot becomes clear. 
tories, and this is unlikely to have been caused by family structures, at least not over the entire course of the CA. On the other hand, given the total duration of the cemetery of some 250 years, as already indicated by the ${ }^{14} \mathrm{C}$-dates prior to any kind of chronological conditioning, it would be anachronistic to assume no internal development of funeral rituals or grave artefacts. It is precisely this long development that can be perceived as representing a linear trend and which, in addition, shows neither a decisive interruption, nor any other kind of discontinuity for that matter. of course, it is to be expected that existing kinship and other social relations are somewhere reflected in the CA. These relations alone, however, are not sufficient to substantiate the specific position of any of the graves within the CA. The grave position is instead due to the wider and much more elaborate sum of all its relations with all the other graves (see below), and this total relation will naturally be much stronger for burials that are closer together in time than those far apart. Taking all these arguments together, we may finally expect all existing gender, kinship and other social relations to merge together and be henceforth visible, although not separately, and indeed only under statistical conditions; but in combination they represent the most important CA factor, which is calendric time.

To evaluate the CA curve shape as a chronological sequence, two different methods are available, which may also be called different perspectives: one is to analyse the sequence of individual (one-by-one) find

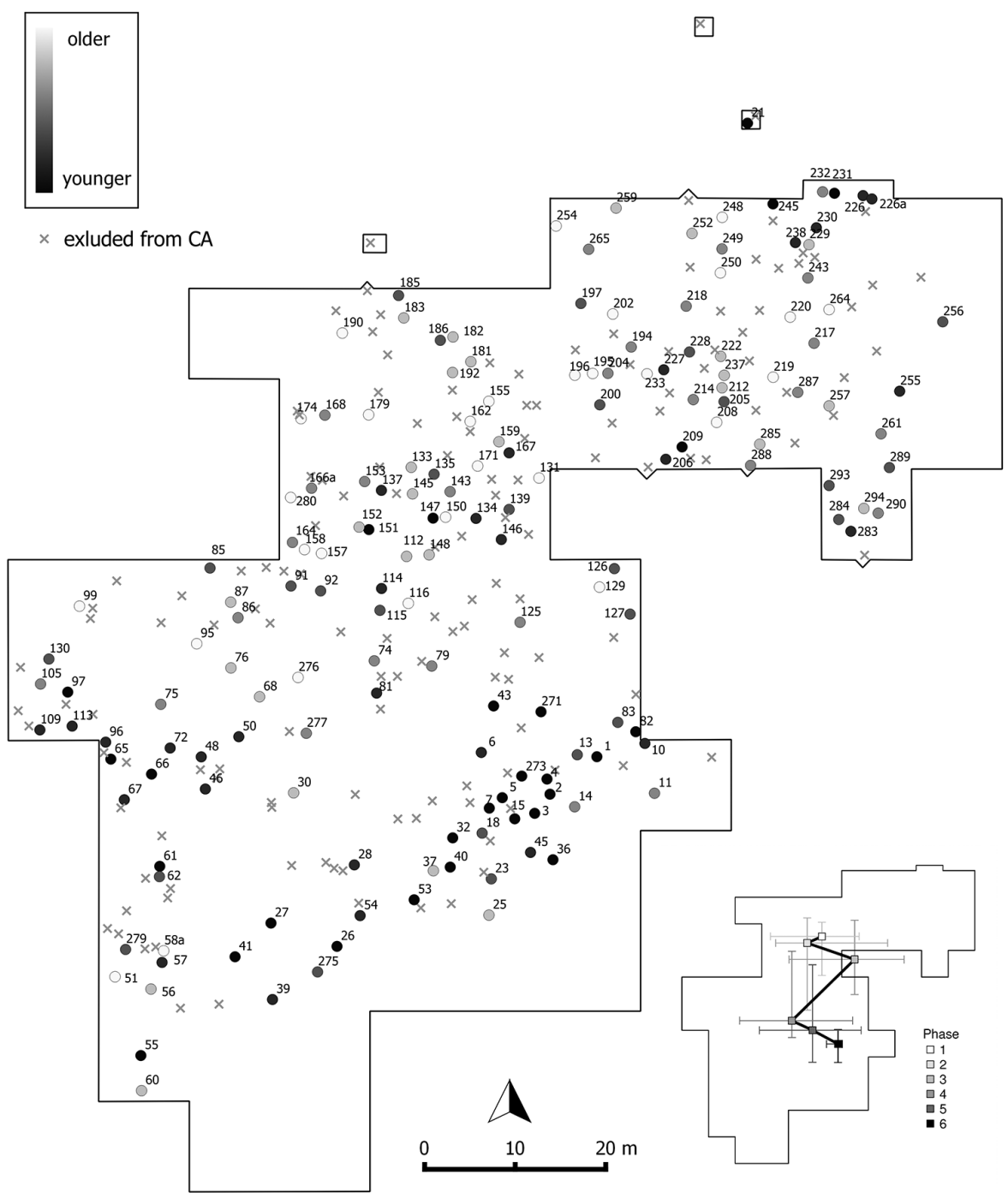

Fig. 3. Varna I. Topographic map of the Varna cemetery, with graves (labelled by numbers) plotted as dots that have variable greyscale intensity. The grey-scale intensity is digitally calibrated (see inlay) from 'old' (light grey) to 'young' (dark black) according the rank order of each specific grave on the CA parabola (shown in Figure 1). Bottom Right: the small map shows the position of the center points by CA-phase, whereas the center is calculated as the median of the coordinate values and the whiskers display the interquartile range. 

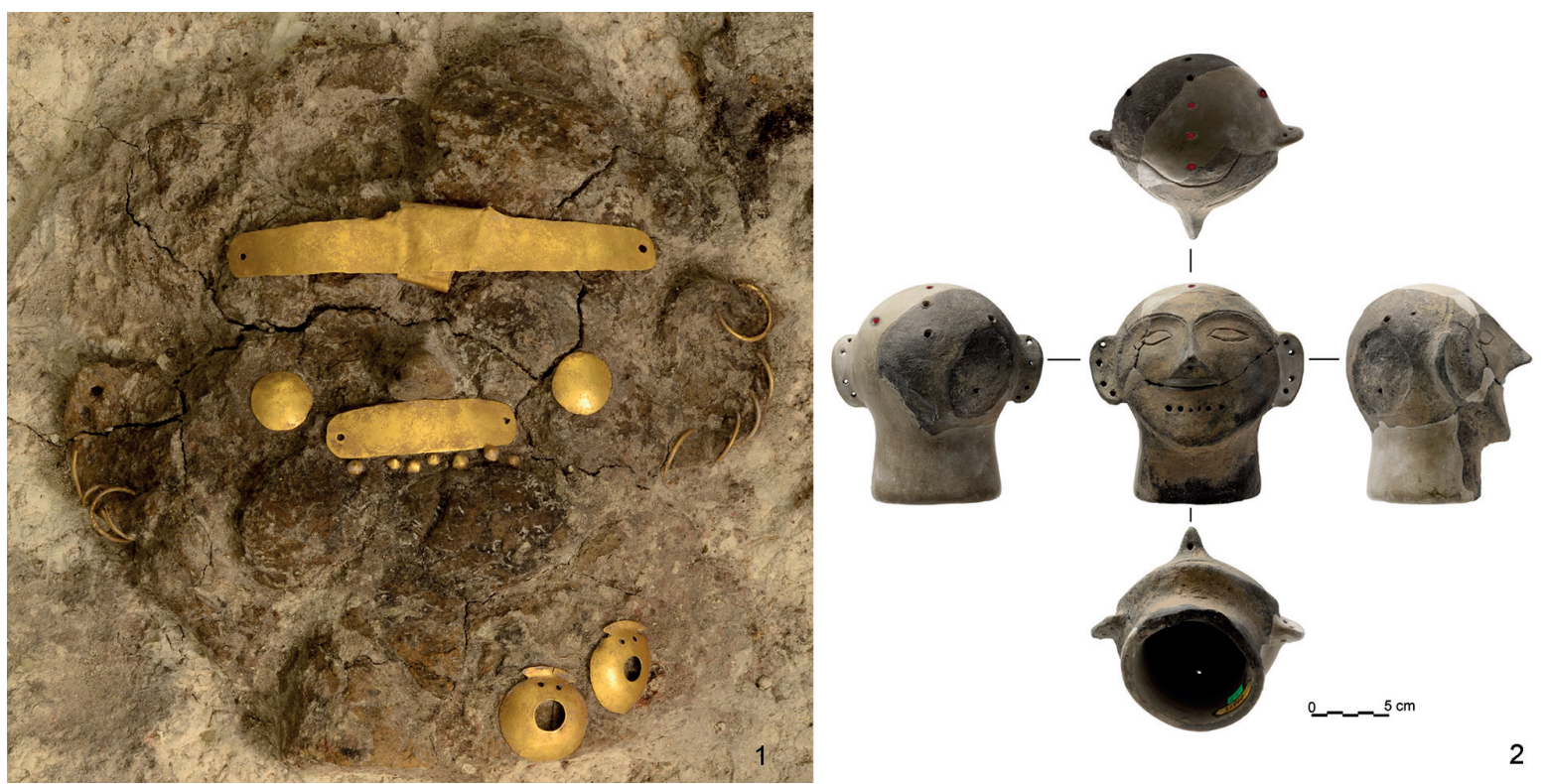

Fig. 4. Varna I. 1 Flat-pressed clay head of an anthropomorphic half life-size figurine from Grave 2. 2 Analogy of such a clay head from Lake Varna at Ezerovo-Arsenala (from Slavčev et al. 2016.Figs. 8, 14).

contexts according to their position on CA factor 1; the other is to define a number of discrete sections on the parabola into which the find contexts can then be grouped. This second method is better suited to describing the overall development of forms within the burial ground, since the subdivision of the parabola into discrete sections enables a comparison of conceived phases. In addition, it is easier to visualise existing gaps and discontinuities between the (2-D) grave clusters on the CA-parabola itself, not by their (1-D) projection onto factor 1 . In comparison, any existing differences in rank order are better visualised in (1-D) barcode plots. We show the existence of major differences between the two methods in Figure 1, where the upper barcode graph (named 'Projection') presents the clearly discrete CA clusters as they appear in their arrangement along the parabola, while the lower barcode graph (named 'Factor 1') displays only their partly overlapping order according to the factor 1 projection (Tab. 1). Finally, in order to describe the beginning, middle, and end of any chronological development, it may seem natural simply to choose the corresponding tripartite division. Instead, we decided upon a division into six phases, whereby it is possible to uniquely identify graves which are transitional between the three parts and to achieve a higher resolution for further observations. Based on the radiocarbon analysis, to be described below, we may assume a total duration of Varna I in the order of 250 years, so the average phase duration amounts to 42 years. Although the respective CA positions and lengths of the six phases proposed here follow to some extent naturally from the course of the CA parabola, due to given variations in the density and clustering properties of the CA, the chosen six-fold subdivision nevertheless results in a somewhat uneven distribution of the graves in terms of their targeted uniform assignation to the beginning, middle and end of the cemetery. This could indeed reflect the actual chronological dynamics of the burial sequence. As shown in the bar chart in the upper left of Figure 1, the number of graves assigned to each of the six phases varies between 14 and 44.

\section{Topographic development of the graves and burial rites}

As a result of the chronological arrangement of the graves that is now available thanks to the CA application, we are immediately provided with some very welcome insights into the topographic (on-site) development of the burial sequence. As can be taken from Figure 3, the burials show a clear tendency to spread over time from the northwest to the southeast parts of the cemetery, in other words from higher to lower ground, and always in towards the bank of Lake Varna. This general trend can also be seen in the sequence of the CA phases' geographic centers (bottom right of Figure 3), which leads us to the interpretation that the first burials were situated in the northwest. Then, during the extensive use of the burial ground, the burials spread widely over the entire space, but mainly in direction of the Lake. This is most evident in the large whiskers of phases 3-5 in Figure 3. At the end period of the necropolis, 
a line of very richly furnished symbolic graves and deposits appears that are most clearly distinguishable in the southwest part of the cemetery, and which simultaneously characterise the end of its occupation. Beyond this, as with the centre of the cemetery, there is a slight scattering of graves with no clear topographic tendency. Furthermore, for a number of burials in both the northern area and southern part, no exact sequence from young to old (or vice versa) can be discerned. This topographic structure of the cemetery would have been even more pronounced if we had included in the phase mapping the many graves which were removed from the CA as outliers due to their scanty burial goods.

These specific inventories were deposited in the ground in a number of rituals over a possibly longer time span, but in each case - due to their quite unusual quality - we can clearly identify the demarcation line between the living and the dead. The three symbolic Graves, 2, 3 and 15, each contain depictions of a human head. These depositions mark a prominent section along the line of graves, which itself appears to represent an entrance to the burial ground. As shown by computer tomography (Slavchev et al. 2016), there is no evidence for 'mask graves' (as was previously assumed). What we instead see in these graves are round plastic figures crushed by the pressure of earth (Fig. 4.1). A parallel might be found in the head that was salvaged from the dredging of Lake Varna at Ezerovo-Arsenala (Fig. 4.2). What we can now safely reconstruct as a component of the
Varna Group is the existence of roughly half life-size figures with clay heads, which were deposited in this section precisely when this burial site fell into disuse.

When one examines the development of grave types within the six phases, a tendency is evident which, despite the meagreness of only 122 identified graves in the CA, harmonises very well with the general historical development of burial customs in the KGK VI Complex, and in particular within the so-called Varna group (cf. Lichter 2001.129-132). At the beginning of the graveyard, crouched burials outnumber supine burials at a ratio of two-to-one, and there are very few symbolic burials (Fig. 5). But already by the second phase, supine burials very clearly dominate, while the rate of crouched burials consistently and continually declines throughout the development of the burial ground. This picture becomes more intelligible with recourse to the burial ground at Durankulak, the advent of which is primarily dominated by supine burials which are seen as a borrowing from the earlier traditions of the Hamangia Culture (Todorova 2002.41-40). In Varna I, it seems that, following an early phase with roughly only a third of burials supine, by the second phase this burial custom becomes generally established. In contrast, the crouched position, with the face turned to the right, is pushed back. An increase in symbolic graves is even more significantly displayed in the statistics of the burial customs. In combination, these tendencies provide reasons to conclude that parallel with the development of the site into an area for promi-

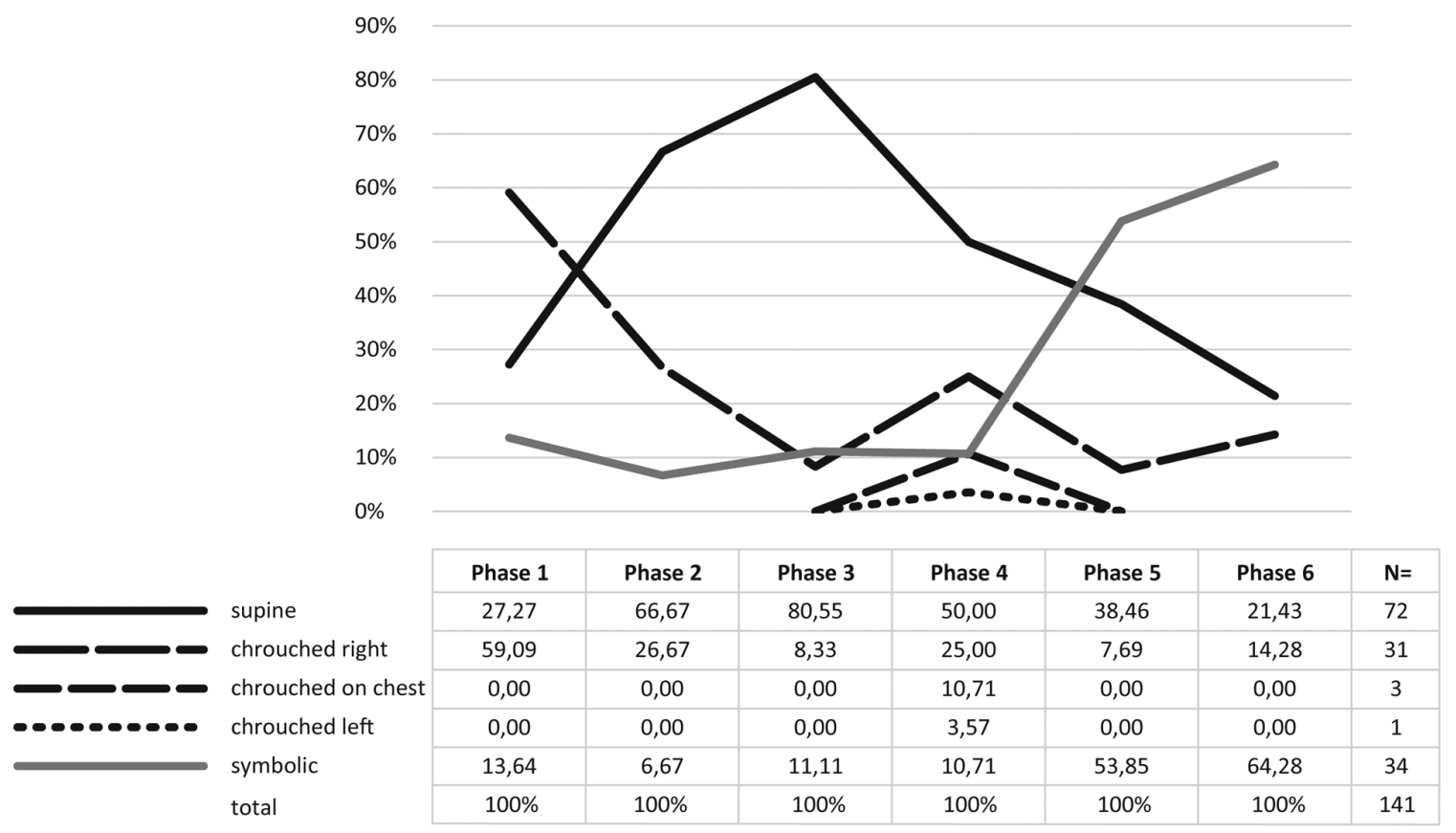

Fig. 5. Varna I. Development of burial rites during cemetery phases 1-6. 


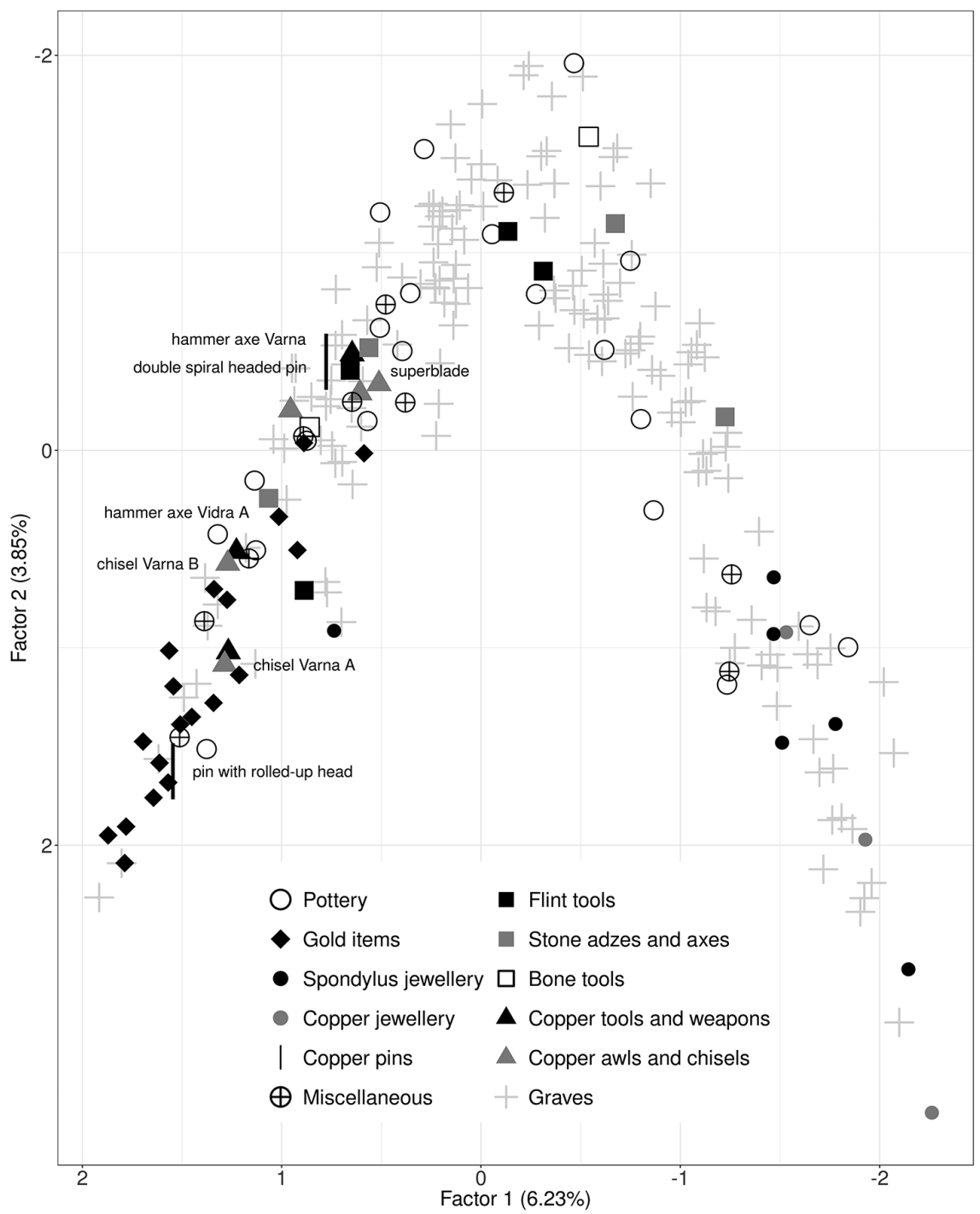

Fig. 6. Varna I. CA based on the filtered data subset (as in Figure 1 but without the 13 additional graves), showing the different artefact types grouped according to mutually exclusive categories. Some artefact types explicitly mentioned in the text are labelled.

nent burials, the rituals occurring around the burials also gained strongly in importance.

Especially instructive for the chronological validity of the CA are the copper tools. The first heavy copper tool to appear is the hammer axe of the Pločnik type, which goes on to endure throughout all phases thereafter. Tellingly, this is one of the typologically oldest forms, since it has a large body reminiscent of its stone predecessors (cf. Vulpe 1975.20; Govedarica 2001.153; Diaconescu 2014). Thereafter in the $\mathrm{CA}$, and more or less consecutively, the various awls, the hammer axes of the Devnja A and Varna types, and then the hammer axes of the Vidra B, Devnja $B$ and Vidra A types appear (Fig. 6). The end of the sequence is also well established in terms of the copper tools, namely by the occurrence of a hammer axe of Vidra $C$ type and chisels of the Varna A and
$B$ variants. In total, the typological spectrum of copper tools and weapons becomes increasingly diverse and technically refined. Starting with modest awls and simple axes (Figs. 7-10), the development in the burial ground of Varna I becomes ever more complex, until even partially hybrid forms of weapons and tools become tangible (Figs. 11-12). At the end of this process, in symbolic Grave 4, we find a elegantly curved axe along with a singular pickaxe (Fig. 12.82 ), as a metallic realisation of an antler pick (Krauß et al. 2014.383, Fig. 10).

The substitution of stone weapons and tools with copper examples can also be seen in the flint artefacts. Generally, the proportion of flint tools declines over the course of the development of Varna I, with the interesting exception of so-called superblades (Manolakakis 2005.273-275; Gurova 2013.387- 
388), but to which we must ascribe some very different functions and meanings: not only do their numbers increase over the course of the development, but superblades are often associated with gold jewellery and heavy copper tools. Focusing on the polished stone tools, it is the adzes originating from the Neolithic tradition which dominate at the beginning. From the middle of the development until its end, what we observe as characteristic are the many finely shaped stone axes, some of which are so delicately worked that it might be surmised they are the symbolic realisations of copper axes.

Also illuminating is the development of items of jewellery made of gold, copper, dentalium and spondylus. At the beginning of the CA, objects fashioned from spondylus and jewellery created from copper predominate. More interesting, however, is the fact that, with the first appearance of gold objects, copper is used increasingly for tools, but no longer for jewellery (Figs. 7-12). Here, a development may be traced which begins with natural materials (spondylus, stone, antler) and further continues with copper as a raw material, before copper itself is replaced by gold in metal jewellery. Copper jewellery occurs only in the early phases, 1 to 3, and thereafter disappears almost entirely. The only copper adornments from the later phases which still appear are pins with rolled-up heads, and double-spiral-headed pins. Interestingly, and quite unlike other copper jewellery, these pins are always associated with gold. They call to mind some double-spiral-headed pins deriving from burnt houses in Pietrele in trenches B and $\mathrm{F}$ (Hansen et al. 2009.56-60). The relevant contexts are dated to $4430-4280 \mathrm{cal} \mathrm{BC}$ and $4410-4260 \mathrm{cal} \mathrm{BC}$, respectively (Hansen et al. 2010.Fig. 2). As will be shown below, both these dates correspond to the end of the CA, in which the double-spiral-head pins also occur in Varna I.

From a chronological perspective, the most convincing development which reveals itself in the CA is that of ceramics, which corresponds entirely (cum grano salis) with the stratigraphic sequences known from the tell settlements of the KGK VI Complex ${ }^{3}$. This having been stated, we can focus on some difficulties that are evident in the development of certain forms that do not appear in the settlements. Presumably, these ceramic forms were either deliberately (and additionally) produced for funerary use, or they were restricted solely to the distribution region of the Varna Group, where they have comparisons with developments at the burial ground of Durankulak, as well as with the burial group at Varna II. Specific comparisons are the ceramic stands which appear in the CA in a development sequence comparable to that of Durankulak (Todorova 2002.86-114). The four-cornered stands of the early phases of Durankulak (Hamangia IV and Varna Group I) are present only at Varna II (Fig. 13). At Varna I, the development begins with such stands, still with very short
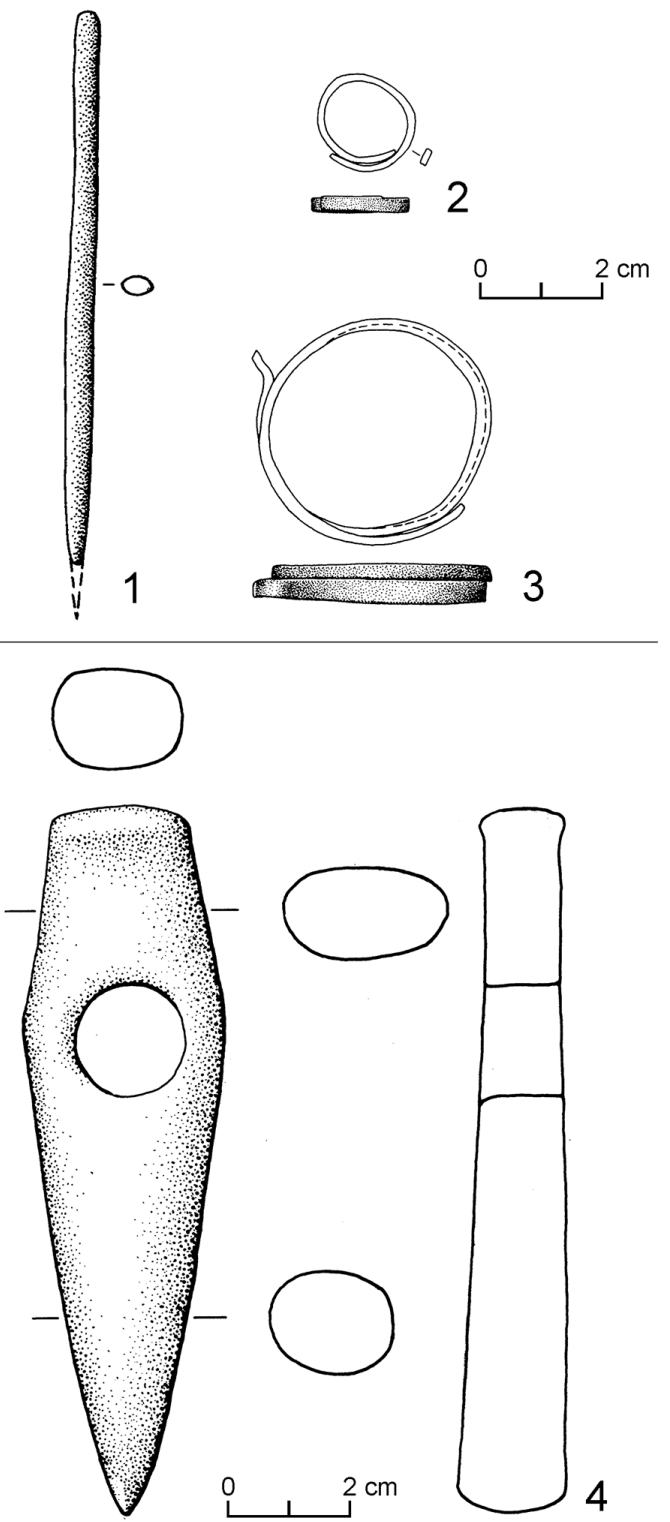

Fig. 7. Varna I. Typical equipment of metal tools and jewellery for the first phase. 1-3 two copper rings and a copper awl from Grave 51 (o", 20-40 years, supine); 4 copper hammer-axe type Pločnik from Grave 116 (o', 7-12 years, supine) (1-3 from Todorova, Vajsov 2001; Todorova 1981; 4 drawing made by Moni Möck. Anthropological determination done by Steve Zäuner).

3 For example, at Goljamo Delčevo V-XVII (Todorova et al. 1975.Taf. 41-108) or Ovčarovo XI-XIII (Todorova et al. 1983.Taf. 78-88). 

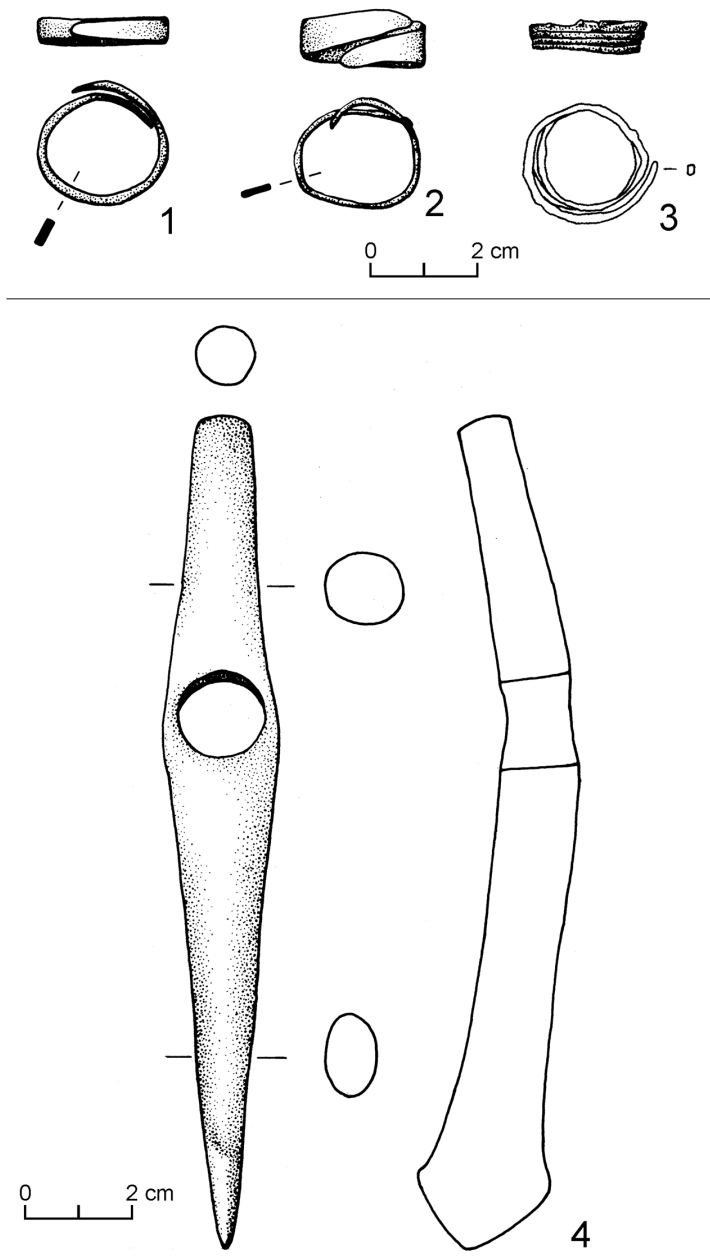

4

Fig. 8. Varna I. Typical metal objects for the second phase. 1-3 three copper rings from Grave 60 (20-40 years, crouched right); 4 copper hammeraxe type Devnja from Grave 229a (anthropologically indeterminable) (1, 2, 4 drawings made by Moni Möck; 3 from Todorova, Vajsov 2001. Anthropological determination done by Steve Zäuner).

points on the rim and the routine incised adornment. From these developed the remaining types over time with their increasingly swollen bodies and increasingly long points, and finally at the very end, ornate examples painted in multiple rows with graphite ornamentation appear. With respect to the vessel inventory from the tell settlements, the Varna vessels, which clearly stand in a Boian tradition, catch the eye at the beginning of the development, including profiled pots, Todorovas 'Steckdosen', spherical-biconic pots, and carinated bowls. Thereafter, classic KGK VI forms follow over the entire development of Varna I. At the end are found bowls with rolled-up or flattened rims, scratch adorned, or graphite painted lids, and fine multi-component pots i.e. the entirety of forms which also occur in the tell settlements at the end of their development. Regarding the wellknown graphite painting, in general terms this ele- ment can be regarded as a constant at Varna I. Already with the Karanovo $\mathrm{V}$ chronological phase ( $\mathrm{Ma}$ rica Culture), this painting technique was established throughout the entire eastern Balkan region. As in the case of the burial ground at Varna I, it appears we record only a section in the middle of the development of graphite painting, and which might similarly be evidenced in many vessels of the so-called Transitional Phase from the Copper to Early Bronze Age.

\section{Network analysis}

The analytical potential of SNA based on archaeological data has been repeatedly demonstrated ( $c f$. Sos$n a$ et al. 2012; Collar et al. 2015) and therefore requires only minimal introduction. Based on the statistical analysis of relationships between different actors, the fundamental concept of SNA is to reveal the underlying socio-structural aspects and social patterns. Applied to the Varna I dataset, the find contexts can be understood as actors, which in the network analysis are represented as nodes, through
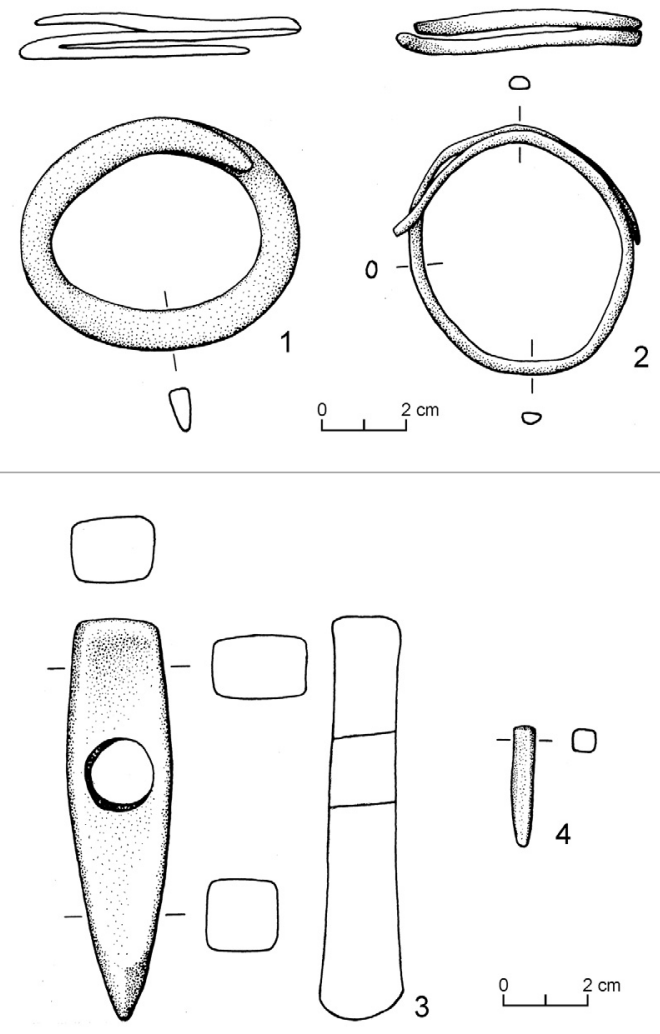

Fig. 9. Varna I. Typical metal objects for the third phase. 1-2 two copper arm-rings from Grave 126 ( $\sigma$, 20+ years, supine); 3-4 copper hammer-axe type Pločnik and copper awl from Grave 143 ( $\sigma$, 30-40 years, supine) (drawings made by Moni Möck. Anthropological determination done by Steve Zäuner. 

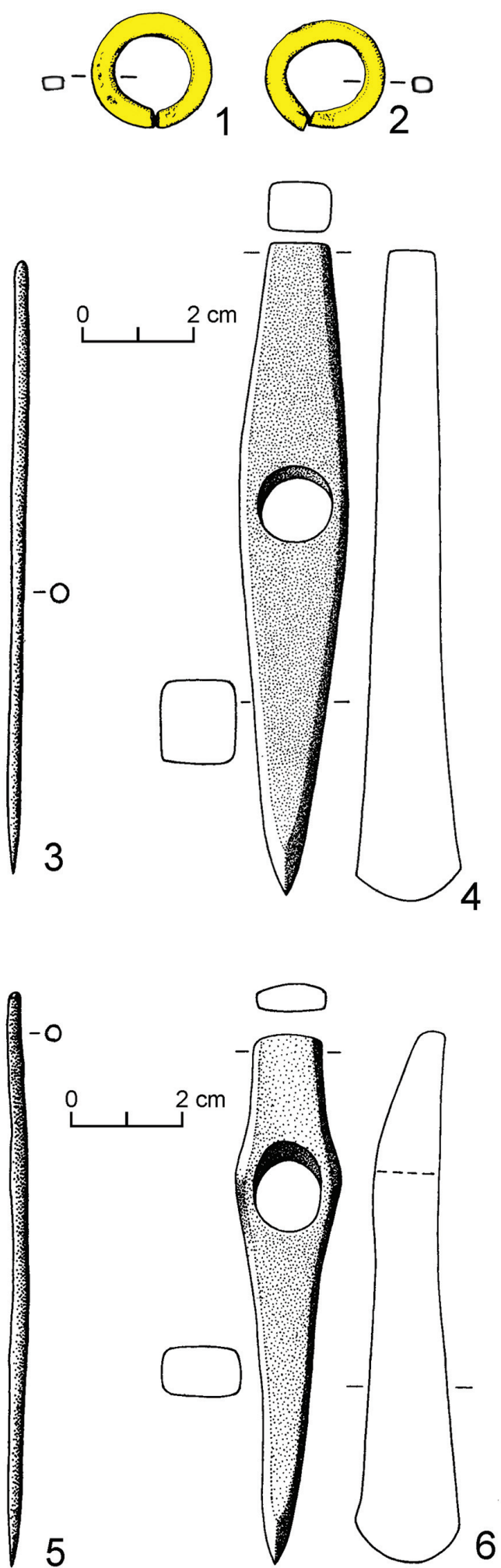

Fig. 10. Varna I. Typical metal objects for the fourth phase. 1-4 two gold rings, a copper awl and a hammer-axe type Čoka-Varna from Grave 6 ( $\sigma^{\circ}$ ?, 30-35 years, supine); 5-6 copper awl and hammer-axe type Vidra B from Grave 92 (0", 50+ years, supine) (1-2 drawings made by Moni Möck; 3-6 from Todorova 1981. Anthropological determination done by Yordan Yordanov (Grave 6) and Steve Zäuner (Grave 92)). which the different grave goods (or other characteristics in the grave furnishing) are inter-related (Serdült 2002.127). The further analytical premise is that, not only does the exclusivity of individual grave goods or the diversity of grave good inventories depict important social markers, but also that some meaning may be assigned to the individual relationships. Grave 43, for example, evidences a quite unusually large number of connections to other graves, many of which are dispersed over the entire area (Fig. 14). It is hardly surprising, then, that this grave is also closely connected to the immediately neighbouring symbolic Graves 1, 2, 3, 4, and 15. The closest connection, however, is to feature 97 , which is spatially located in the western area of the burial ground. What SNA also uncovers is a particular proximity between Grave 43 and the features 283 and 290 in the north-eastern part of the graveyard.

The application of SNA now allows us to further unravel the complex reasons why Grave 43 takes on its specific position on the CA curve. Essentially, the position of Grave 43 is due to its many close connections with the similar furnishing characteristics of Graves 1, 3, 4, 15, and 97, all of which date to the younger end of the CA. Nevertheless, there are a small number of features in Grave 43 which are also characteristic of the beginning of the CA. Through these few conservative elements, if only next to the generally high degree of connection, Grave 43 displays a relatively broad cross-section of the grave goods that are found in the funerary rituals. This is a specific property that Grave 43 has in common with the large majority of over-furnished graves. With the application of SNA, not only does the marked interconnection of Grave 43 within the complete relationship network of the Varna cemetery funerary rituals become clearer, but this presumably partly also explains why Chapman et al. developed a ${ }^{14} \mathrm{C}$ based chronology for the Varna cemetery which runs backwards in time (Chapman et al. 2006; Higham et al. 2007; 2008). An additional explanation for this major dating bias may also be due to the independent but chance combination of two major distorting effects: (1) an unduly smoothed construction of the calibration curve for ages around $4380 \mathrm{cal} \mathrm{BC}$, and (2) the human 'old-age' ${ }^{14} \mathrm{C}$-residence effect for Grave 43 itself (see below).

\section{Modelling of the radiocarbon dates}

In order to establish a CA-based ${ }^{14} \mathrm{C}$-chronology for the Varna I cemetery, we have at our disposal a total of 74 radiocarbon ages for archaeological contexts 
from the Copper Age (Mathieson et al. 2017; Krauß et al. 2014. Tab. 2; Higham et al. 2017.Tab. 1; in print) (Tab. 2). Two additional dates (Poz-71453; OxA-19872) belong to Bronze Age burials at the site. Another two dates (MAMS15093; MAMS-15094) were processed on dentalium shells from symbolic graves, but are not further analysed here due to their clear reservoir effects. In the following, we describe the chronological results achieved by applying the 'Gaussian Monte Carlo Wiggle Matching' (GMCWM) method, which is integrated in the ${ }^{14} \mathrm{C}$-age calibration software CalPal (Cologne Radiocarbon Calibration and Palaeoclimate Research Package). The present analysis is based on the internationally recommended ${ }^{14} \mathrm{C}$-age calibration curve INTCAL 13 (Reimer et al. 2013). Following the often lengthy GMCWM run-times, which typically require some 6-10 hours, the final quality control is performed by visual inspection of the calculated bestfit' position of the Varna data sequence, in comparison - not with the calibration curve itself - but with the raw data of the ${ }^{14} \mathrm{C}$-AMS laboratories that participated in the construction of INTCAL13. We regularly use this procedure, since it helps in recognising the potentially disturbing impact of remaining weaknesses in the shape of the calibration curve due to variations in data density, for example, or other kinds of statistical unevenness (e.g., over-smoothing of wiggles).

The applied GaussWM procedure is based on an extension of the now classical wiggle-matching method (Pearson 1980), whereby the archaeological sample sequence is fitted to the calibration curve by minimising the summed distances between the ${ }^{14} \mathrm{C}$-ages, as measured on the samples, and corresponding values of the calibration curve, as measured on dendrodated wood samples of potentially the same calendar age. In the present application, the archaeological sequence is based on a uniform-phase model such that, depending on which grave was dated, the corresponding ${ }^{14} \mathrm{C}$-age is assigned to one of the six different CA-phases. In modelling, each phase is then assigned an equal calendric time-span, whereby the phase-internal position of each ${ }^{14} \mathrm{C}$-age is chosen according
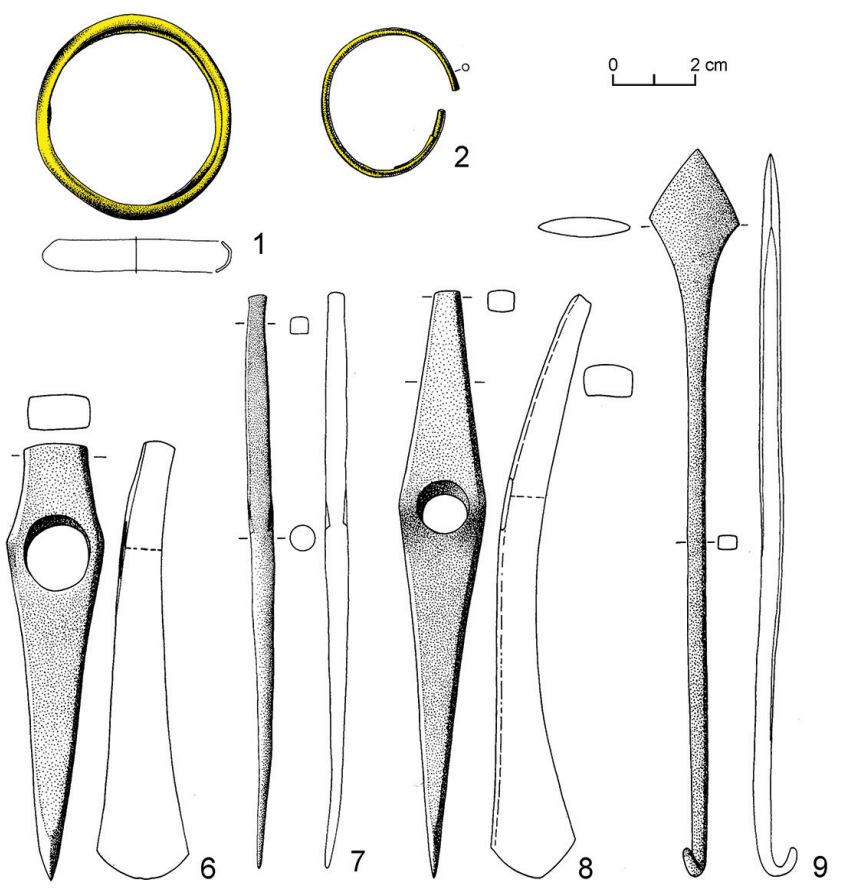

Fig. 11. Varna I. Typical metal objects for the fifth phase: two golden rings, a jewellery chain with a ring idol, a golden appliqué and en ring idol, a copper awl, spearhead and hammer-axes of type Vidra B and type Varna from symbolic Grave 97 (1-5 from Todorova, Vajsov 2001; 6-9 from Todorova 1981).

to the CA-order (rank along the regression curve). During run-time, the time-span assigned to each phase is stepwise expanded; this is aimed at finding the statistically best-fitting overall time-span. Finally, also during run-time, we quantitatively account for cal-scale errors $\left(\sigma_{\text {cal }}\right)$ in the CA-position of each dated grave, as well as for possible interlaboratory offsets $\left(\sigma_{\mathrm{BP}}\right)$ on the ${ }^{14} \mathrm{C}$-scale, by applying Gaussian variability of $\sigma_{\mathrm{cal}}= \pm 10[\mathrm{a}]$ and $\sigma_{\mathrm{BP}}= \pm 10[\mathrm{BP}]$ to these parameters. The hypothetical re-measurement of each archaeological ${ }^{14} \mathrm{C}$-age is allowed by applying Gaussian variability to the measured ${ }^{14} \mathrm{C}$-ages based on given standard deviations.

Notably, in this study we have for the first time applied a data-fitting method known as 'non-central Chi-squared' data fitting, which is described in more detail in the Rogue Wave ${ }^{\circledR}$ Fortran Numerical Libraries (IMSL $\AA$ Version 6). To be specific, in programming the $\chi^{2}$-methodology, we use the IMSL $₫$ CSNDF library with a (typical) choice of non-centrality variable $\lambda=5$. The use of non-central $\chi^{2}$-statistics has proven useful not only for the Varna data, but quite generally for cases when the statistical relation between the ${ }^{14} \mathrm{C}$-age calibration curve and the topological structure of the archaeological data is 'asymmetric'. This is best exemplified in the present study by the clearly artificial position of the ${ }^{14} \mathrm{C}$-age on the 


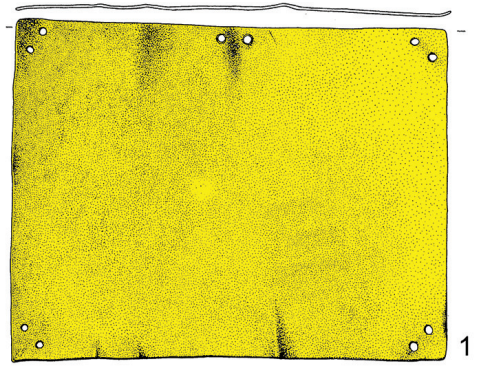

0000000000

$\triangle \triangle \triangle \triangle \Lambda \triangle \triangle \triangle \triangle \triangle \triangle \triangle$

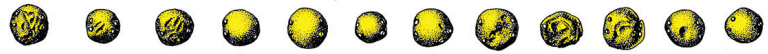

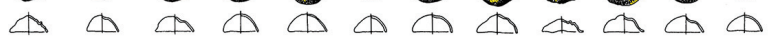

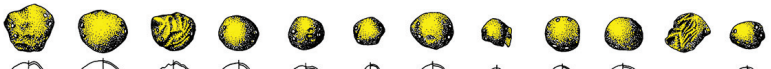

$\triangle \wedge \Delta \wedge \Delta \Delta \Delta a \Delta \Delta \cos \Delta$

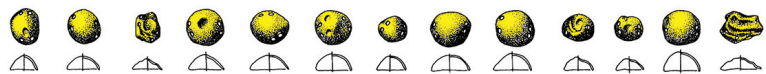

$2-50$

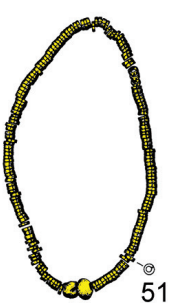

$2 \mathrm{~cm}$
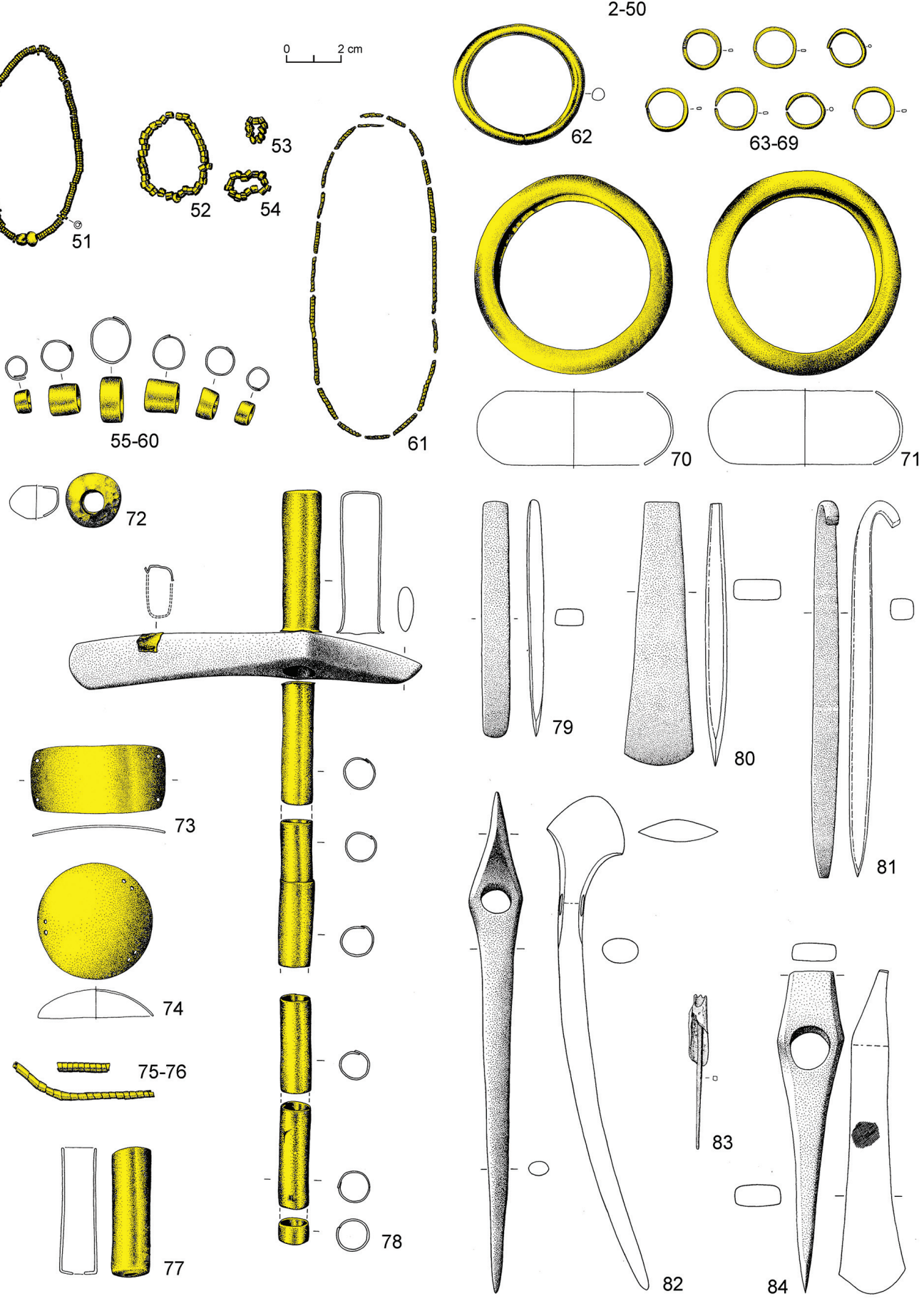

Fig. 12. Varna I. Typical metal objects for the sixth phase: gold applications, jewellery chains of gold beads, gold rings, golden arm rings, gold clasps of a bow, a stone axe sceptre with gilded shaft, two copper adzes, a shafted copper spike, a copper pick and a hammer-axe type Vidra B from symbolic Grave 4 (1-78 from Todorova, Vajsov 2001; 79-84 from Todorova 1981). 


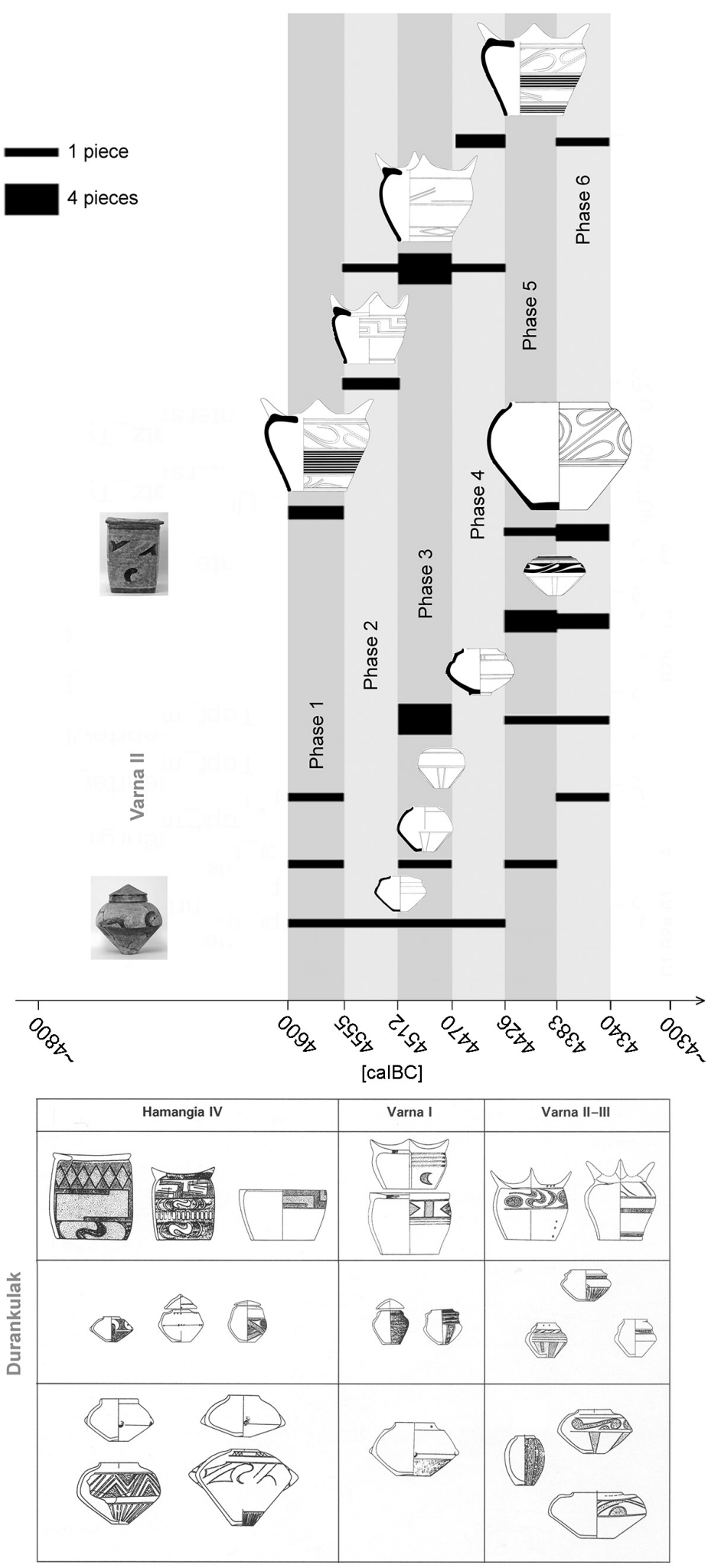

Fig.13. Varna I, Varna II and Durankulak. Comparison of the sequence for ceramic stands and profiled pots. The development of forms is based on a spindle diagram of all pottery types in Varna I. The absolute timeline (4300-4800 cal BC) of the pottery development is scaled according to the CA-based ${ }_{14}$ C-chronology, with shading details (4340-4600 cal BC) based on the precisely ( \pm 20 yrs) determined time intervals for Varna phases 1-6 (see Figs. 1; 16). elderly man (age > 60 yrs) from Grave 43 at a ${ }^{14} \mathrm{C}$-value $(\sim 5700 \mathrm{BP})$ that is so high above the (presumably) itself strongly over-smoothed calibration curve that it may even appear to be a major outlier (cf. Fig. 15). In our view, such a large ${ }^{14} \mathrm{C}$ offset for the burial in Grave 43 can be satisfactorily explained only if we assume an additive combination of (1) the existence of a presently undocumented wiggle in the tree-ring ${ }^{14} \mathrm{C}$-age calibration curve at around $4380 \pm 20 \mathrm{cal} \mathrm{BC}$, and (2) an additional offset of some 30-50 BP for the senior citizen in Grave 43 due to the human ${ }^{14} \mathrm{C}$-residence ('adult') effect (e.g., Geyh 2001; Hedges et al. 2007).

Conspicuously, as can be taken from Figure 15, essentially two different (alternative) solutions exist for the task of deriving a statistically 'optimal' model-chronology for the CA-seriated Varna I data, which we describe as a 'long' (primary) and a 'shorter/older' (secondary) chronology. Ultimately, the existence of such multiple solutions to the task of finding a statistically 'optimal' wiggle-matching result, although seldom discussed in the relevant literature, is not at all unexpected. It is simply a consequence, for larger data sets, analogous to the well-known existence of multiple readings for single ${ }^{14} \mathrm{C}$ ages. As it transpired, both solutions are highly robust and producible (as should be the case for larger data sets). For the sake of interest in such 'quantisation properties' of archaeological radiocarbon data, we nevertheless tested the co-existence of these two solutions under a wide spectrum of different methods and conditions $\left(e . g\right.$., non-central $\chi^{2}$ with values $0<\lambda<20$; different age-models; randomising and non-randomising sample order; systematic offsets between male and female etc.). Although a fair amount of unexplained variability exists, as it appears, both solutions actually do reflect the characteristic wiggle pattern of the calibration curve in combination with the given data. We finally adopted what can be termed the 'long' Varna I chronology (Fig. 16), for which the analysis most often showed the better statistical values in respect to the two parameters under study 


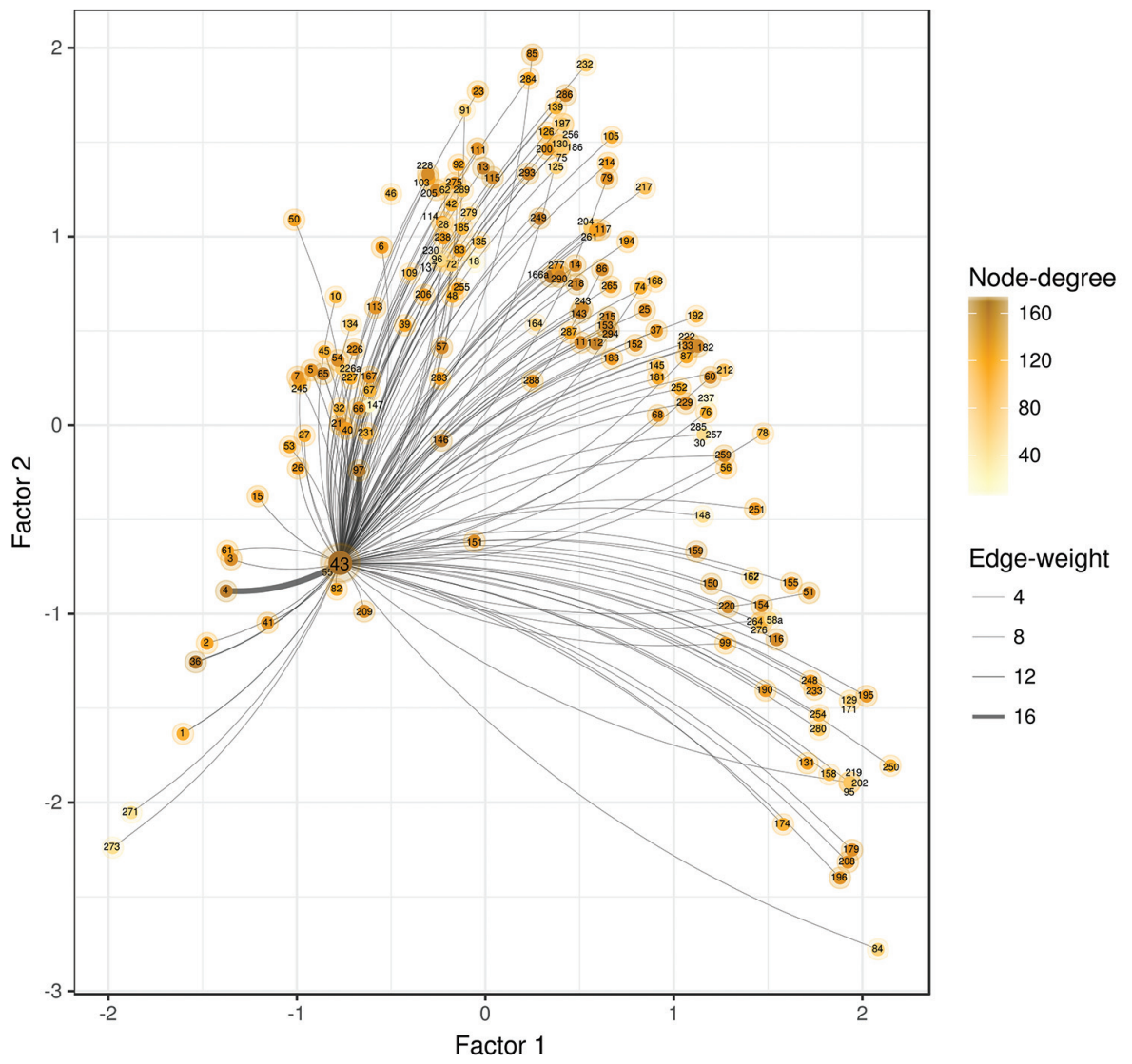

Fig. 14. Varna I. Results of Social Network Analysis (SNA) mapped onto the CA plot (cf. Fig. 1). The graph shows the attributes of grave 43 scaled both according to their chronological development in the CA as well as in relation to the other graves. Node-degree (colour-intensity-scaled) describes the total number of features that are shared by grave 43 and every other (labelled) grave. Edge-weight (line-width-scaled) reflects features common to two graves.

(probability and precision). The specific advantage of using the non-central $\chi^{2}$-method (with, for example, $\lambda=5$ ) was that, although the results were similar to those achieved by the standard $\chi^{2}$-method $(i$. e. $\lambda=0$ ), the run-time necessary to achieve clearly convergent results was an order of magnitude shorter (1 hour instead of 8$)$. Also noteworthy is that the chronological results are completely robust with respect to any chance random permutation of the established grave order, and also robust regarding the definition of what may or may not be extreme values. We also used random shuffle algorithms to check that the chronological boundaries of the different CA-phases (1-6) change only insignificantly when moving data between neighbouring phases.

Our main result, shown in Figure 16, is not only that the cemetery begins at $4590 \mathrm{cal} \mathrm{BC}$ and ends at 4340 cal BC. In addition, by combining the radiocarbon ages with the results of correspondence analysis, we achieved a reasonably precise chronology (decadelscale errors) for each grave in the CA, whether it is directly ${ }^{14} \mathrm{C}$-dated or not. This is important, and de- serves repeating with different wording, namely: with the achieved age-calibration of the CA-scale, it is now possible to derive a calendric date for any requested grave (assuming it contains a certain minimal number of grave-goods), simply by looking up its CA position. If we now also generalise our understanding of the previously obtained age reversal, whereby a development from rich graves to poorer burials was postulated (Higham et al. 2007), this is apparently due to the lack of numeric (metric) archaeological information in age-model construction. Whatever the true explanation, this chronology strongly opposes the cultural-historical reality. Only through the applied metric-scaled grave order (used in GMCWM) in contrast to the ordinal-scaled grave order (applied in Bayesian Sequencing), but even then only by applying additional cemetery-external dating knowledge to the CA-results, was it possible to identify the graves belonging to the beginning and end of the necropolis. This order is presumably confirmed by a new series of ${ }^{14} \mathrm{C}$-dates with Lab-Codes 0xA-23611 to 0xA-23626, but which we could not yet include in the analysis. 

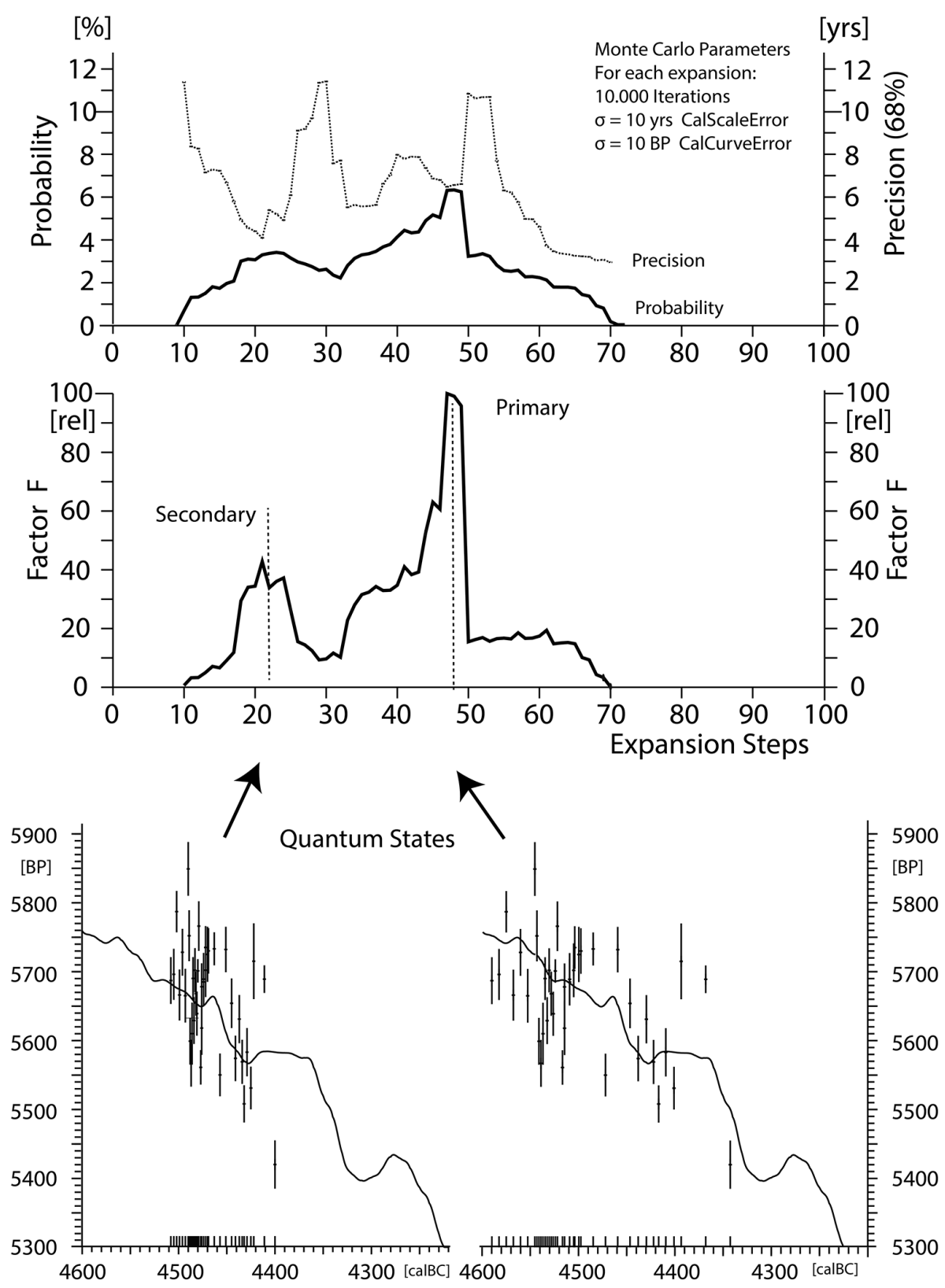

Fig. 15. Varna I. Three graphs that illustrate the existence of essentially two different solutions for the chronological sequence of Varna I ${ }^{14}$ C-ages.

GaussWM-Methodology: during run-time (typically 6-8 hrs), the 6-phase Varna age-model is stepwise linearly expanded, whereby for each step the best-fitting overall length of the sample sequence is calculated and stored. Typically, the expansion is run some 1-500 times ('repetitions'); in each case, the complete expansion is subdivided into 1-100 steps, and at each step the entire age-model is varied some 10010000 times.

Upper Graph: following (in this case) some 600000 re-modelling calculations $(10000$ iterations $* 60$ steps), two graphs are produced, one of which shows the (accumulated) probability as a function of the incremental expansion. The other shows the accumulated precision of best-fitting calendric ages (defined as 68\%-width of the corresponding histogram). Middle Graph: when all runs are completed, an optimisation factor = probability/precision is defined, which represents (simultaneously) the maximum in probability and minimum in precision. The bimodal shape of Factor $F$, which can also be seen independently in probability and precision (cf. Upper Graph), is highly indicative of the existence of two quite distinct 'optimal' solutions (named Primary and Secondary). Both solutions have relatively high maximum Chisquared probabilities (typically 5-10\%, depending on model details), but the Primary solution has the typically higher probability. Lower Graph: schematic comparison of the Primary (P) and Secondary (S) age-models, showing that - in addition to its typically higher probability - the P-model (4345-4590 cal BC) completely encompasses the S-model (4400-4520 cal BC). 


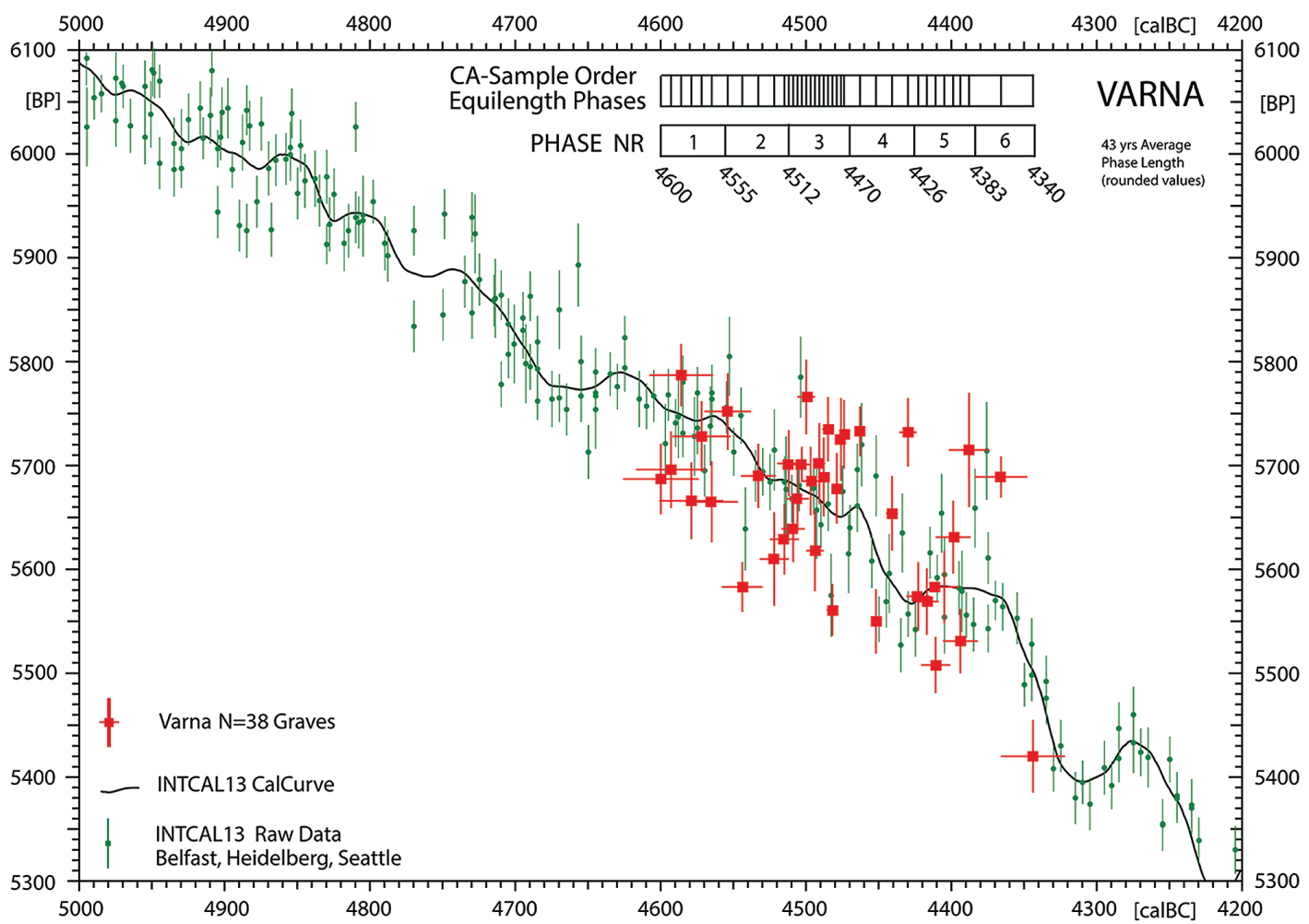

Fig. 16. Varna I. Radiocarbon chronology based on $38{ }^{14}$ C-dated graves (Tab. 1) analysed by the method of GMCWM. This graph shows the best-fitting sequence of ${ }^{14} \mathrm{C}$-ages when modelled according to the CAresults, both in comparison to the INTCAL 13-curve (Reimer et al. 2013) and the raw data used in INTCAL13-construction. For the given time-window (4200-5000 cal BC) INTCAL13 is based on measurements by the laboratories Belfast, Heidelberg and Seattle (data available at http://www.radiocarbon.org/Int Cal13.htm).

To conclude, the derived time of around 250 years for the Varna I cemetery, when now compared with the overall sum of 270 (currently known) burials, provides us with a number of guidelines as to the role of the burial ground in the wider context of the KGK VI Complex. Even allowing for remaining unexcavated areas of the burial site, the annual frequency ( $\sim 1$ per year) of presently documented burials is clearly far too low, even if we assumed just a single settlement. To the same question, furthermore, the proportion of burials in comparison with the large number of symbolic burials indicates that a variety of individuals was buried at Varna I, quite possibly from different settlements. The striking importance of the northern littoral of Lake Varna for contemporary Chalcolithic societies is already eluci- dated in the existence of the Varna II burial group, and this is, of course, further demonstrated by the exceptional richness of Varna I. Also remarkable, however, is the appearance of the symbolic graves on the south-eastern edge of the burial ground, through which the site was finally sacralised. Nevertheless, the search for a settlement that corresponds to the necropolis on grounds of the demographic data and now largely clarified chronological depth may be less expedient than perhaps anticipated. Rather, we should perceive Varna I as a prominent burial site within a larger settlement area of the KGK VI Complex, and which certainly encompasses the known tell settlements in the hinterland of the western Black Sea Coast. 


\section{References}

Chapman J., Higham T., Slavčev V., Gaydarska B. and Honch N. 2006. The Social Context of the Emergence, Development and Abandonment of the Varna Cemetery, Bulgaria. European Journal of Archaeology 9: 159-183.

Diaconescu D. 2014. New remarks about the typology and the chronology of the Pločnik and Čoka copper hammeraxes. In W. Schier, F. Drassovean (eds.), The Neolithic and Eneolithic in Southeast Europe. New Approaches to Dating and Cultural Dynamics in the $6^{\text {th }}$ to $4^{\text {th }}$ Millennium BC. Prähistorische Archäologie in Südosteuropa 28. Rahden: 221-241.

Dimitrov K. 2002. Die Metallfunde aus den Gräberfeldern von Durankulak. In H. Todorova (ed.), Durankulak Band II. Die prähistorischen Gräberfelder von Durankulak 2. Sofija: 126-158.

Collar A., Coward F. S., Brughmans T. and Mills B. J. 2015. Networks in archaeology. Phenomena, abstraction, representation. Journal of archaeological method and theory 22: $1-32$.

Geyh M. 2001. Bomb Radiocarbon Dating of Animal Tissues and Hair. Radiocarbon 43(2B): 723-730.

Govedarica B. 2001. Zur Typologie und Chronologie der Hammeräxte vom Typ Pločnik. In R. M. Boehmer (ed.), Lux Orientis. Archäologie zwischen Asien und Europa. Festschrift für Harald Hauptmann zum 65. Geburtstag. Internationale Archäologie Studia honoraria 12. Rahden: 153-164.

Gurova M. 2013. Towards the Meaning of Flint Grave Goods: A case study from Bulgaria. In A. Comşa, C. Bonsall and L. Nikolova (eds.), Facets of the past. The challenge of the Balkan Neo-Eneolithic: Proceedings of the International Symposium celebrating the 85th birth anniversary of Eugen Comsa: 6-12 October 2008, Bucharest, Romania. Editura Acedemie Române. Bucharest: 375-393.

Hansen S., Toderas M., Reingruber A., Becker N., Gatsov I., Kay M., Nedelcheva P., Prange M., Röpke A. and Wunderlich J. 2009. Pietrele. Der kupferzeitliche Siedlungshügel "Măgura Gorgana" und sein Umfeld: Bericht über die Ausgrabungen und geomorphologischen Untersuchungen im Sommer 2008. Eurasia Antiqua 15: 15-66.

Hansen S., Toderas M., Reingruber A., Gatsov I., Kay M., Nedelcheva P., Nowacki D., Röpke A., Wahl J. and Wunderlich J. 2010. Pietrele, "Măgura Gorgana". Bericht über die Ausgrabungen und geomorphologischen Untersuchungen im Sommer 2009. Eurasia Antiqua 16: 43-96.
Hedges R. E. M., Clement J. G., Thomas C. D. L. and O'Connel T. C. 2007. Collagen Turnover in the Adult Femoral Mid-Shaft: Modeled From Anthropogenic Radiocarbon Tracer Measurements. American Journal of Physical Anthropology 133: 808-816.

Higham T., Slavčev V. and Chapman J. 2007. New perspectives on the Varna cemetery (Bulgaria), AMS dates and social implications. Antiquity 81: 640-654.

Higham T., Chapman J., Gaydarska B. and Slavčev V. 2008. The first AMS dates for the Varna cemetery. Acta Musei Varnaensis VI: 95-114.

Higham T., Slavchev V., Gaydarska B. and Chapman J. in print. AMS dating of the Late Copper Age Varna cemetery, Bulgaria. Radiocarbon 59.

Ivanov I. 1978. Rannohalkolitni grobove do grad Varna. Izvestiya Muzej Varna 14: 81-92.

Krauß R., Zäuner S. and Pernicka E. 2014. Statistical and Anthropological Analysis of the Varna Necropolis. In R. Risch, H. Meller and E. Pernicka (eds.), Metalle der Macht - Frühes Gold und Silber. 6. Mitteldeutscher Archäologentag vom 17. bis 19. Oktober 2013 in Halle (Saale). Tagungen des Landesmuseums für Vorgeschichte Halle 11/II. Halle: 371-387.

Lichter C. 2001. Untersuchungen zu den Bestattungssitten des südosteuropäischen Neolithikums und Chalkolithikums. Univ. Diss. Heidelberg 1999. Monographien/ Heidelberger Akademie der Wissenschaften. Internationale Interakademische Kommission für die Erforschung der Vorgeschichte des Balkans 5. Zabern. Mainz am Rhein.

Manolakakis L. 2005. Les industries lithiques énéolithiques de Bulgarie. Marie Leidorf. Rahden.

Mathieson I. and 111 co-authors. 2017. The Genomic History of Southeastern Europe. BioRxiv. doi.org/10.1101/ 135616.

Reimer P. J. and 29 co-authors. 2013. INTCAL13 and Marine INTCAL13 Radiocarbon Age Calibration Curves 050,000 years Cal BP. Radiocarbon 55(4): 1869-1887.

Serdült U. 2002. Soziale Netzwerkanalyse. Eine Methode zur Untersuchung von Beziehungen zwischen sozialen Akteuren. Österreichische Zeitschrift für Politikwissenschaft 31: 127-141.

Sosna D., Galeta P., Smejda L., Sladek V. and Bruzek J. 2013. Burials and Graphs. Relational Approach to Mor- 
tuary Analysis. Social Science Computer Review 31: 5670 .

Slavchev V., Dimitrov K. and Etzel M. 2016. Die Komplexe 2, 3 und 15 mit Gesichtsdarstellungen aus dem kupferzeitlichen Gräberfeld von Varna. In V. Nikolov, W. Schier (eds.), Der Schwarzmeerraum vom Neolithikum bis in die Früheisenzeit (6000-600 v.Chr.): Kulturelle Interferenzen in der zirkumpontischen Zone und Kontakte mit ihren Nachbargebieten. Prähistorische Archäologie in Südosteuropa 30: 141-164.

Todorova H. 1981. Die kupferzeitlichen Äxte und Beile in Bulgarien. Prähistorische Bronzefunde IX(14). Beck'sche Verlagsbuchhandlung München. München.

2002. Die archäologische Geschlechtsbestimmung. In H. Todorova (ed.), Durankulak Band II. Die prähisto- rischen Gräberfelder von Durankulak 2. Deutsches Archäologisches Institut in Berlin. Sofia: 53-60.

Todorova H., Vajsov I. 2001. Der kupferzeitliche Schmuck Bulgariens. Prähistorische Bronzefunde XX.6. Franz Steiner Verlag. Stuttgart.

Todorova H., Ivanov St., Vasilev V., Hopf M., Quitta H. and Kohl G. 1975. Selishtnata mogila pro Golyamo Delchevo. Razkopki I prouchvaniya 5. Bulgarska Akademiya na Naukite. Sofia.

Todorova H., Vasilev V., Yanushevich Z., Kovacheva M. and Valev P. 1983. Ovcharovo. Razkopki I prouchvaniya 9. Bulgarska Akademiya na Naukite. Sofia.

Vulpe A. 1975. Die Äxte und Beile in Rumänien. Prähistorische Bronzefunde IX(5). Beck'sche Verlagsbuchhandlung München. München. 
Tab. 1. Varna I. Results of CA and rank order analysis of the filtered and enlarged data-subset (cf. Figure 1). The first two result dimensions of the CA are presented in comparison to their 'projected' counterparts. Each grave is assigned a rank and phase according to its position along the regression curve. The coordinates are rounded up to four decimal places.

\begin{tabular}{|c|c|c|c|c|c|c|c|c|c|c|c|c|c|}
\hline grave & $\begin{array}{c}\text { e factor } \\
1\end{array}$ & $\begin{array}{c}\text { factor } \\
2\end{array}$ & $\begin{array}{c}\text { factor } 1 \\
\text { projection }\end{array}$ & $\begin{array}{c}\text { factor } 2 \\
\text { projection }\end{array}$ & rank & hase & grave & factor & $\begin{array}{c}\text { factor } \\
2\end{array}$ & $\begin{array}{c}\text { factor } 1 \\
\text { projection }\end{array}$ & $\begin{array}{c}\text { factor } 2 \\
\text { projection }\end{array}$ & rank & hase \\
\hline 273 & $-1,9763$ & $-2,2391$ & $-1,8103$ & $-2,2869$ & 177 & 6 & 255 & $-0,1464$ & 0,7236 & $-0,2719$ & 0,9072 & 128 & 4 \\
\hline 271 & $-1,8777$ & $-2,0533$ & $-1,7528$ & $-2,0904$ & 176 & 6 & 230 & $-0,2384$ & 0,8771 & $-0,2626$ & 0,9134 & 127 & 4 \\
\hline 1 & $-1,6034$ & $-1,6358$ & $-1,6116$ & $-1,6331$ & 175 & 6 & 96 & $-0,2384$ & 0,877 & $-0,2626$ & 0,9134 & 126 & 4 \\
\hline 36 & $-1,5366$ & $-1,2562$ & $-1,4912$ & $-1,2719$ & 174 & 6 & 137 & $-0,232$ & 0,8702 & $-0,2613$ & 0,9143 & 125 & 4 \\
\hline 2 & $-1,4768$ & $-1,1558$ & $-1,4534$ & $-1,1641$ & 173 & 6 & 72 & $-0,1804$ & 0,848 & $-0,2323$ & 0,9328 & 124 & 4 \\
\hline 41 & $-1,1554$ & $-1,0479$ & $-1,3809$ & $-0,9641$ & 172 & 6 & 81 & $-0,208$ & 0,929 & $-0,2159$ & 0,9426 & 123 & 4 \\
\hline 4 & $-1,3747$ & $-0,8795$ & $-1,3523$ & $-0,888$ & 171 & 6 & 238 & $-0,2209$ & 0,9922 & $-0,1988$ & 0,9523 & 122 & 4 \\
\hline 3 & $-1,3485$ & $-0,7108$ & $-1,2923$ & $-0,733$ & 170 & 6 & 114 & $-0,2288$ & 1,0755 & $-0,1734$ & 0,9657 & 121 & 4 \\
\hline 209 & $-0,6426$ & $-0,9865$ & $-1,2912$ & $-0,7301$ & 169 & 6 & 28 & $-0,2194$ & 1,069 & $-0,1691$ & 0,9679 & 120 & 4 \\
\hline 61 & $-1,3683$ & $-0,6666$ & $-1,28$ & $-0,7018$ & 168 & 6 & 83 & $-0,1368$ & 0,9251 & $-0,1595$ & 0,9725 & 119 & 4 \\
\hline 82 & $-0,7884$ & $-0,8699$ & $-1,2699$ & $-0,6766$ & 167 & 6 & 103 & $-0,3011$ & 1,3058 & $-0,1494$ & 0,9773 & 118 & 4 \\
\hline 55 & $-0,7953$ & $-0,7447$ & $-1,2249$ & $-0,5664$ & 166 & 6 & 228 & $-0,3045$ & 1,3295 & $-0,1453$ & 0,9792 & 117 & 4 \\
\hline 43 & $-0,7696$ & $-0,7306$ & $-1,2157$ & $-0,5442$ & 165 & 6 & 205 & $-0,2587$ & 1,2467 & $-0,1405$ & 0,9814 & 116 & 4 \\
\hline 15 & $-1,2075$ & $-0,3762$ & $-1,1538$ & $-0,3997$ & 164 & 6 & 62 & $-0,2148$ & 1,2526 & $-0,1124$ & 0,9931 & 115 & 4 \\
\hline 26 & $-0,9938$ & $-0,2292$ & $-1,0616$ & $-0,1971$ & 163 & 5 & 42 & $-0,1786$ & 1,1679 & $-0,1105$ & 0,9939 & 114 & 4 \\
\hline 151 & $-0,0579$ & $-0,6152$ & $-1,0352$ & $-0,1421$ & 162 & 5 & 18 & $-0,0591$ & 0,8649 & $-0,1095$ & 0,9943 & 113 & 4 \\
\hline 53 & $-1,0383$ & $-0,1143$ & $-1,0249$ & $-0,1208$ & 161 & 5 & 185 & $-0,1234$ & 1,0432 & $-0,1053$ & 0,9959 & 112 & 4 \\
\hline 97 & $-0,6707$ & $-0,2408$ & $-1,0025$ & $-0,0754$ & 160 & 5 & 275 & $-0,1611$ & 1,283 & $-0,0723$ & 1,0075 & 111 & 4 \\
\hline 27 & $-0,9591$ & $-0,0552$ & $-0,9856$ & $-0,0418$ & 159 & 5 & 289 & $-0,1205$ & 1,2445 & $-0,0538$ & 1,0132 & 110 & 4 \\
\hline 40 & $-0,738$ & $-0,0192$ & $-0,9222$ & 0,0798 & 158 & 5 & 279 & $-0,0823$ & 1,1225 & $-0,0514$ & 1,0138 & 109 & 4 \\
\hline 21 & $-0,7698$ & 0,0049 & $-0,9192$ & 0,0854 & 157 & 5 & 135 & $-0,0311$ & 0,9691 & $-0,0438$ & 1,016 & 108 & 4 \\
\hline 231 & $-0,6273$ & $-0,0432$ & $-0,9063$ & 0,1091 & 156 & 5 & 92 & $-0,1417$ & 1,3806 & $-0,0434$ & 1,0161 & 107 & 4 \\
\hline 32 & $-0,774$ & 0,0866 & $-0,8847$ & 0,1484 & 155 & 5 & 91 & $-0,1102$ & 1,6698 & 0,0059 & 1,0272 & 106 & 4 \\
\hline 245 & $-0,9833$ & 0,224 & $-0,8761$ & 0,1637 & 154 & 5 & 111 & $-0,0416$ & 1,4662 & 0,0234 & 1,03 & 105 & 4 \\
\hline 7 & $-0,9959$ & 0,2556 & $-0,8659$ & 0,1817 & 153 & 5 & 13 & $-0,0114$ & 1,3641 & 0,0326 & 1,0314 & 104 & 4 \\
\hline 66 & $-0,6697$ & 0,0906 & $-0,8567$ & 0,1979 & 152 & 5 & 23 & $-0,0396$ & 1,7697 & 0,0434 & 1,0327 & 103 & 4 \\
\hline 147 & $-0,617$ & 0,1028 & $-0,837$ & 0,2317 & 151 & 5 & 115 & 0,0391 & 1,3132 & 0,0614 & 1,0344 & 102 & 4 \\
\hline 5 & $-0,9236$ & 0,2909 & $-0,8335$ & 0,2379 & 150 & 5 & 284 & 0,2302 & 1,8373 & 0,1564 & 1,0338 & 101 & 3 \\
\hline 65 & $-0,8604$ & 0,2721 & $-0,8255$ & 0,2514 & 149 & 5 & 85 & 0,2497 & 1,9647 & 0,1593 & 1,0336 & 100 & 3 \\
\hline 146 & $-0,2329$ & $-0,0817$ & $-0,8158$ & 0,2677 & 148 & 5 & 293 & 0,2277 & 1,3334 & 0,1845 & 1,0305 & 99 & 3 \\
\hline 67 & $-0,6144$ & 0,1829 & $-0,7989$ & 0,2955 & 147 & 5 & 126 & 0,3271 & 1,5509 & 0,219 & 1,0245 & 98 & 3 \\
\hline 227 & $-0,7144$ & 0,2493 & $-0,7965$ & 0,2995 & 146 & 5 & 139 & 0,3746 & 1,682 & 0,2282 & 1,0226 & 97 & 3 \\
\hline $226 a$ & $-0,7629$ & 0,2995 & $-0,7872$ & 0,3146 & 145 & 5 & 200 & 0,3307 & 1,4643 & 0,2306 & 1,022 & 96 & 3 \\
\hline 54 & $-0,7821$ & 0,3442 & $-0,7725$ & 0,3381 & 144 & 5 & 286 & 0,4266 & 1,7486 & 0,2439 & 1,0189 & 95 & 3 \\
\hline 45 & $-0,8536$ & 0,3891 & $-0,7725$ & 0,3382 & 143 & 5 & 127 & 0,4118 & 1,5953 & 0,2551 & 1,016 & 94 & 3 \\
\hline 167 & $-0,6139$ & 0,2553 & $-0,7644$ & 0,3509 & 142 & 5 & 197 & 0,4118 & 1,5953 & 0,2551 & 1,016 & 93 & 3 \\
\hline 226 & $-0,6967$ & 0,4046 & $-0,7195$ & 0,4199 & 141 & 5 & 130 & 0,3943 & 1,4802 & 0,2622 & 1,014 & 92 & 3 \\
\hline 134 & $-0,7131$ & 0,5323 & $-0,6654$ & 0,4981 & 140 & 5 & 186 & 0,3943 & 1,4802 & 0,2622 & 1,014 & 91 & 3 \\
\hline 283 & $-0,2398$ & 0,2472 & $-0,6337$ & 0,5414 & 139 & 5 & 256 & 0,3943 & 1,4802 & 0,2622 & 1,014 & 90 & 3 \\
\hline 10 & $-0,7938$ & 0,6799 & $-0,6253$ & 0,5526 & 138 & 5 & 75 & 0,3943 & 1,4802 & 0,2622 & 1,014 & 89 & 3 \\
\hline 113 & $-0,5831$ & 0,6232 & $-0,5751$ & 0,6167 & 137 & 5 & 249 & 0,2876 & 1,0955 & 0,264 & 1,0135 & 88 & 3 \\
\hline 39 & $-0,4264$ & 0,53 & $-0,5569$ & 0,6388 & 136 & 5 & 232 & 0,5336 & 1,909 & 0,2687 & 1,0121 & 87 & 3 \\
\hline 50 & $-1,0132$ & 1,0884 & $-0,5307$ & 0,6696 & 135 & 5 & 125 & 0,3768 & 1,365 & 0,2709 & 1,0114 & 86 & 3 \\
\hline 57 & $-0,2302$ & 0,4118 & $-0,5288$ & 0,6718 & 134 & 5 & 105 & 0,6715 & 1,5269 & 0,3861 & 0,965 & 85 & 3 \\
\hline 206 & $-0,324$ & 0,6894 & $-0,4177$ & 0,7883 & 133 & 4 & 214 & 0,6507 & 1,3895 & 0,4099 & 0,9524 & 84 & 3 \\
\hline 6 & $-0,5485$ & 0,9435 & $-0,4101$ & 0,7954 & 132 & 4 & 79 & 0,6466 & 1,3072 & 0,4307 & 0,9405 & 83 & 3 \\
\hline 109 & $-0,3992$ & 0,8034 & $-0,4002$ & 0,8045 & 131 & 4 & $166 a$ & 0,3478 & 0,7877 & 0,4372 & 0,9366 & 82 & 3 \\
\hline 48 & $-0,1739$ & 0,6825 & $-0,3201$ & 0,8721 & 130 & 4 & 277 & 0,3837 & 0,8233 & 0,4495 & 0,9291 & 81 & 3 \\
\hline 46 & $-0,5$ & 1,2247 & $-0,2773$ & 0,9035 & 129 & 4 & 204 & 0,5551 & 1,0488 & 0,4685 & 0,917 & 80 & 3 \\
\hline
\end{tabular}




\begin{tabular}{|c|c|c|c|c|c|c|c|c|c|c|c|c|c|}
\hline grave & $\begin{array}{c}\text { factor } \\
1\end{array}$ & $\begin{array}{c}\text { factor } \\
2\end{array}$ & $\begin{array}{c}\text { factor } 1 \\
\text { projection }\end{array}$ & $\begin{array}{l}\text { factor } 2 \\
\text { projection }\end{array}$ & & & grave & $\begin{array}{c}\text { factor } \\
1\end{array}$ & $\begin{array}{c}\text { factor } \\
2\end{array}$ & $\begin{array}{c}\text { factor } 1 \\
\text { projection }\end{array}$ & $\begin{array}{c}\text { factor } 2 \\
\text { projection }\end{array}$ & & \\
\hline 290 & 0,3956 & 0,7862 & 0,4792 & 0,9098 & 79 & 3 & 285 & 1,1554 & $-0,048$ & 1,1909 & $-0,03$ & 39 & 2 \\
\hline 261 & 0,5842 & 1,033 & 0,4919 & 0,9011 & 78 & 3 & 30 & 1,1554 & $-0,048$ & 1,1909 & $-0,03$ & 38 & 2 \\
\hline 117 & 0,6078 & 1,0359 & 0,5042 & 0,8924 & 77 & 3 & 78 & 1,4741 & $-0,0445$ & 1,2513 & $-0,152$ & 37 & 2 \\
\hline 14 & 0,4779 & 0,847 & 0,5086 & 0,8892 & 76 & 3 & 259 & 1,2674 & $-0,1613$ & 1,2579 & $-0,1659$ & 36 & 2 \\
\hline 164 & 0,267 & 0,5345 & 0,5271 & 0,8753 & 75 & 3 & 56 & 1,2784 & $-0,2288$ & 1,286 & $-0,2252$ & 35 & 2 \\
\hline 217 & 0,8471 & 1,2578 & 0,5393 & 0,8659 & 74 & J & 148 & 1,1545 & $-0,4819$ & 1,3612 & $-0,3909$ & 34 & 1 \\
\hline 218 & 0,486 & 0,7474 & 0,5665 & 0,8439 & 73 & 3 & 251 & 1,4312 & $-0,4446$ & 1,3919 & $-0,4615$ & 33 & 1 \\
\hline 86 & 0,6197 & 0,8256 & 0,6055 & 0,8099 & 72 & 3 & 59 & 1,119 & $-0,6695$ & 1,4256 & $-0,5412$ & 32 & 1 \\
\hline 194 & 0,7542 & 0,9719 & 0,6065 & 0,8091 & 71 & 3 & 150 & 1,1986 & $-0,842$ & 1,4996 & $-0,7228$ & 31 & 1 \\
\hline 243 & 0,5141 & 0,617 & 0,6575 & 0,7605 & 70 & 3 & 57 & 1,4144 & $-0,8083$ & 1,5174 & $-0,768$ & 30 & 1 \\
\hline 143 & 0,5034 & 0,5953 & 0,6638 & 0,7541 & 69 & 3 & 162 & 1,4144 & $-0,8083$ & 1,5174 & $-0,768$ & 29 & 1 \\
\hline 265 & 0,6655 & 0,7345 & 0,6745 & 0,7432 & 68 & 3 & 220 & 1,2867 & $-0,9627$ & 1,5533 & $-0,861$ & 28 & 1 \\
\hline 287 & 0,4493 & 0,4906 & 0,6955 & 0,7212 & 67 & & 155 & 1,6236 & $-0,8387$ & 1,5548 & $-0,8649$ & 27 & 1 \\
\hline 74 & 0,8232 & 0,728 & 0,7477 & 0,663 & 66 & 3 & 154 & 1,4664 & $-0,9563$ & 1,5741 & $-0,9159$ & 26 & 1 \\
\hline 288 & 0,2507 & 0,2333 & 0,7493 & 0,6612 & 65 & 3 & 51 & 1,7175 & $-0,8887$ & 1,5828 & $-0,9391$ & 25 & 1 \\
\hline 215 & 0,6532 & 0,5719 & & 0,657 & 64 & 3 & $58 a$ & 1,5128 & $-1,0254$ & 1,6026 & $-0,9923$ & 24 & 1 \\
\hline 11 & 0,5065 & 0,4377 & 0,7581 & 0,6507 & 63 & 3 & 264 & 1,4629 & $-1,0477$ & 1,6038 & $-0,9957$ & 23 & 1 \\
\hline 168 & 0,9035 & 0,7608 & 0,764 & 0,6438 & 62 & 3 & 276 & 1,4629 & $-1,0477$ & 1,6038 & $-0,9957$ & 2 & 1 \\
\hline 153 & 0,64 & 0,5247 & 0,772 & 0,6341 & 61 & 3 & 99 & 1,2739 & $-1,1571$ & 1,617 & $-1,0317$ & 21 & 1 \\
\hline 294 & 0,6546 & 0,4993 & 0,7919 & 0,6098 & 60 & 3 & 116 & 1,5452 & $-1,1364$ & 1,6423 & $-1,1015$ & 20 & 1 \\
\hline 112 & 0,5871 & 0,4326 & 0,7987 & 0,6013 & 59 & 3 & 190 & 1,4866 & $-1,407$ & 1,7212 & $-1,3267$ & 19 & 1 \\
\hline 25 & 0,8462 & 0,6088 & 0,8132 & 0,583 & 58 & 3 & 248 & 1,7255 & $-1,3573$ & 1,731 & $-1,3554$ & 18 & 1 \\
\hline 183 & 0,672 & 0,3522 & 0,8762 & 0,4986 & 57 & 2 & 233 & 1,7456 & $-1,4014$ & 1,7465 & $-1,4011$ & 17 & 1 \\
\hline 152 & 0,7966 & 0,4246 & 0,8845 & 0,487 & 56 & 2 & 129 & 1,9341 & $-1,4611$ & 1,783 & $-1,5108$ & 16 & 1 \\
\hline 37 & 0,9076 & o,4997 & 0,8862 & 0,4846 & 55 & 2 & 171 & 1,9341 & $-1,4611$ & 1,783 & $-1,5108$ & 15 & 1 \\
\hline 192 & 1,1188 & 0,5781 & 0,9168 & 0,4405 & 54 & 2 & 195 & 2,0225 & $-1,4356$ & 1,7841 & $-1,5141$ & 14 & 1 \\
\hline 222 & 1,0785 & 0,4393 & 0,9656 & 0,3667 & 53 & 2 & 254 & 1,7706 & $-1,5371$ & 1,7896 & $-1,5309$ & 13 & 1 \\
\hline 145 & 0,913 & 0,3117 & 0,9754 & 0,3514 & 52 & 2 & 280 & 1,7712 & $-1,6134$ & 1,8122 & $-1,6002$ & 12 & 1 \\
\hline 133 & 1,0812 & 0,4093 & 0,9795 & 0,3449 & 51 & 2 & 131 & 1,7087 & $-1,7916$ & 1,8582 & $-1,7445$ & 11 & 1 \\
\hline 182 & 1,1271 & 0,4187 & 0,9879 & 0,3316 & 50 & 2 & 158 & 1,8249 & $-1,8519$ & 1,8859 & $-1,833$ & 10 & 1 \\
\hline 87 & 1,0668 & 0,3625 & 0,996 & 0,3186 & 49 & 2 & 250 & 2,149 & $-1,8054$ & 1,901 & $-1,8817$ & 9 & 1 \\
\hline 181 & 0,916 & 0,2505 & 1,0044 & 0,3049 & 48 & 2 & 95 & 1,9331 & $-1,8949$ & 1,9074 & $-1,9028$ & 8 & 1 \\
\hline 252 & 1,0334 & 0,1951 & 1,0605 & 0,2108 & 47 & 2 & 202 & 1,9331 & $-1,8949$ & 1,9074 & $-1,9028$ & 7 & 1 \\
\hline 60 & 1,1945 & 0,2541 & 1,0748 & 0,1859 & 46 & 2 & 219 & 1,9331 & $-1,8949$ & 1,9074 & $-1,9028$ & 6 & 1 \\
\hline 212 & 1,2653 & 0,2912 & 1,0761 & 0,1835 & 45 & 2 & 174 & 1,5799 & $-2,1162$ & 1,9394 & $-2,0079$ & 5 & 1 \\
\hline 68 & 0,9152 & 0,0522 & 1,0939 & 0,1521 & 44 & 2 & 179 & 1,9451 & $-2,2518$ & 2,0063 & $-2,234$ & 4 & 1 \\
\hline 229 & 1,0634 & 0,1156 & 1,1022 & 0,1371 & 43 & 2 & 208 & 1,9231 & $-2,3158$ & 2,0217 & $-2,2874$ & 3 & 1 \\
\hline 237 & 1,177 & 0,139 & 1,1187 & 0,1072 & 42 & 2 & 196 & 1,8816 & $-2,4001$ & 2,041 & $-2,3546$ & 2 & 1 \\
\hline 76 & 1,1729 & 0,0671 & 1,1475 & 0,0536 & 41 & 2 & 84 & 2,0825 & $-2,7792$ & 2,1534 & $-2,76$ & 1 & 1 \\
\hline 257 & 1,1554 & $-0,048$ & 1,1909 & $-0,03$ & 40 & 2 & & & & & & & \\
\hline
\end{tabular}


Tab. 2. AMS dated graves of the Varna I necropolis. For the $813 \mathrm{C}$ values, see the original publications. The truth-values given in columns 2 and 7 ('heading') indicate whether (T), or not (F), the respective graves are part of the CA and the radiocarbon model. Sex and age determinations were made by Steve Zäuner (Tübingen); burial postures were taken from the catalogue of individual graves made by Ivan Ivanov and revisited by Vladimir Slavchev. Symbols 9 and $\sigma^{\prime \prime}$ are given for certain, (†) and ( $\left.\sigma^{\prime}\right)$ for most likely and $\left(\left({ }^{\circ}\right)\right)$ and $\left(\left(\sigma^{\prime}\right)\right)$ unsure sex determination. For multiple data used for modelling are given the weighted averages ( $\mu$ ) and Chi-Square Probability Test-Values (p).

\begin{tabular}{|c|c|c|c|c|c|c|c|}
\hline Grave & CA & LabCode & $\begin{array}{l}\text { 14C-Age } \\
\text { [BP] }\end{array}$ & Material & Burial Type & $\begin{array}{l}\text { Radiocarbon } \\
\text { Model }\end{array}$ & Ref \\
\hline 10 & $\mathrm{~T}$ & OxA-13687 & $5569 \pm 32$ & bone human & $\begin{array}{l}\text { sex \& age unclear, crouched } \\
\text { left lying on the back }\end{array}$ & $T$ & (1) \\
\hline 11 & $\mathrm{~T}$ & OxA-13686 & $5639 \pm 32$ & bone human & $\begin{array}{l}\text { sex \& age unclear, crouched } \\
\text { right }\end{array}$ & $\mathrm{T}$ & $(1)$ \\
\hline 25 & $\mathrm{~T}$ & OxA-19867 & $5629 \pm 34$ & bone human & o $20-40$ yrs, supine & $\mathrm{T}$ & (3) \\
\hline 27 & $\mathrm{~T}$ & MAMS-15093 & $6158 \pm 24$ & shell Dentalium & symbolic & $\mathrm{F}$ & $(2)$ \\
\hline 28 & $\mathrm{~T}$ & $\begin{array}{l}\text { OxA-18575 } \\
\text { OxA-23611 } \\
\text { OxA-23612 }\end{array}$ & $\begin{array}{l}5550 \pm 31 \\
5574 \pm 31 \\
5590 \pm 31\end{array}$ & $\begin{array}{l}\text { bone animal } \\
\text { bone human } \\
\text { bone deer }\end{array}$ & $60-70$ yrs, posture unclear & T: OxA-18575 & (3) \\
\hline 30 & $\mathrm{~T}$ & $\begin{array}{l}\text { OxA-19868 } \\
\text { OxA-19869 }\end{array}$ & $\begin{array}{l}5567 \pm 34 \\
5599 \pm 34\end{array}$ & $\begin{array}{l}\text { bone human } \\
\text { bone human }\end{array}$ & $\begin{array}{l}\text { (\$) } 12-15 \text { yrs, crouched } \\
\text { right (?) }\end{array}$ & $\begin{array}{l}\text { T: } N=2 \text { OxA-19868 } \\
\text { and OxA-1 } 19869, \mu= \\
5583(24) B P, p=51 \%\end{array}$ & (3) \\
\hline 32 & $\mathrm{~T}$ & OxA-19870 & $5631 \pm 35$ & bone human & $\sigma^{\circ} 16-19 \mathrm{yrs}$, supine & T & (3) \\
\hline 33 & $\mathrm{~F}$ & Poz-71453 & $3585 \pm 35$ & bone human & $(\stackrel{\circ}{)} 7 \pm 2 \mathrm{yrs}$, crouched right & $F$ (Bronze Age) & (5) \\
\hline 34 & $\mathrm{~F}$ & OxA-19871 & $5638 \pm 35$ & bone human & $\sigma^{\prime} 30-40$ yrs, supine & $\mathrm{F}$ & (3) \\
\hline 38 & $\mathrm{~F}$ & OxA-19872 & $3728 \pm 31$ & bone human & (9) $40+y r s$, crouched left & F (Bronze Age) & (3) \\
\hline 40 & $\mathrm{~T}$ & OxA-24044 & $5531 \pm 31$ & animal bone & symbolic (Figurine) & T & (3) \\
\hline 41 & $\mathrm{~T}$ & MAMS-15094 & $6118 \pm 24$ & shell Dentalium & symbolic & $\mathrm{F}$ & $(2)$ \\
\hline 43 & $\mathrm{~T}$ & $\begin{array}{l}\text { OxA-13685 } \\
\text { MAMS-15095 }\end{array}$ & $\begin{array}{l}5720 \pm 29 \\
5662 \pm 27\end{array}$ & $\begin{array}{l}\text { bone human } \\
\text { bone human }\end{array}$ & ơ $50-65$ yrs, supine & $\begin{array}{l}\mathrm{T}: \mathrm{N}=2 \mathrm{MAMS}-15098 \\
\text { and OxA-13685, } \mu= \\
5689(20) \mathrm{BP}, \mathrm{p}=14 \%\end{array}$ & (3) \\
\hline 44 & $\mathrm{~F}$ & OxA-13692 & $5657 \pm 30$ & bone human & (9) $13+y r s$, supine (?) & $\mathrm{F}$ & $(1)$ \\
\hline 45 & $\mathrm{~T}$ & OxA-19873 & $5583 \pm 35$ & bone human & $\left(\sigma^{\prime}\right) 16-25$ yrs, supine & $T$ & (3) \\
\hline 46 & $\mathrm{~T}$ & OxA-23613 & $5585 \pm 32$ & bone human & (\%) $60+y r s$, crouched on chest & $\mathrm{F}$ & (3) \\
\hline 47 & $\mathrm{~F}$ & OxA-23614 & $5658 \pm 32$ & bone human & ( $\left.\sigma^{\circ}\right) 20-40$ yrs, supine & $\mathrm{F}$ & (3) \\
\hline 50 & $T$ & OxA-19874 & $5574 \pm 33$ & bone human & () $18-25 \mathrm{yrs}$, supine & $T$ & (3) \\
\hline 51 & $\mathrm{~T}$ & OxA-19875 & $5849 \pm 39$ & bone human & $\left(\sigma^{\prime}\right) 20-40$ yrs, supine & $\mathrm{F}$ & (3) \\
\hline 67 & $\mathrm{~T}$ & OxA-23615 & $5717 \pm 32$ & bone human & (o) $40+$ yrs, posture unclear & $\mathrm{F}$ & (3) \\
\hline & & OxA-23616 & $5719 \pm 32$ & bone human & & & \\
\hline 69 & $\mathrm{~F}$ & OxA-19876 & $5608 \pm 35$ & bone human & $\left(\left(\sigma^{\prime}\right)\right) 20+y r s$, supine & $\mathrm{F}$ & (3) \\
\hline 72 & $T$ & OxA-23617 & $5739 \pm 32$ & bone human & $\begin{array}{l}\left(\sigma^{\prime}\right) 50-60 \text { yrs, crouched lying } \\
\text { on the back }\end{array}$ & $\mathrm{F}$ & (3) \\
\hline 78 & $\mathrm{~T}$ & $\begin{array}{l}\text { OxA-19928 } \\
\text { OxA-19929 }\end{array}$ & $\begin{array}{l}5752 \pm 37 \\
5831 \pm 39\end{array}$ & $\begin{array}{l}\text { bone human } \\
\text { bone human }\end{array}$ & $\begin{array}{l}\sigma^{\prime} 20-30 \text { yrs, posture unclear } \\
\text { (and bones of a not archaeo- } \\
\text { logically recorded second } \\
\text { individual: }\left[\sigma^{\circ}\right] 20+\text { yrs) }\end{array}$ & $\begin{array}{l}\mathrm{T}: \mathrm{N}=2 \text { OxA-19928 } \\
\text { and OxA-19929, } \mu= \\
5789(27) \text { BP, } p=14 \%\end{array}$ & (3) \\
\hline 84 & $\mathrm{~T}$ & OxA-19877 & $5687 \pm 34$ & bone human & $\begin{array}{l}1-6 \text { yrs, crouched lying on the } \\
\text { back (and bones of a not } \\
\text { archaeologically recorded } \\
\text { second individual: } 913 \pm 1 \text { yrs) }\end{array}$ & $T$ & (3) \\
\hline 85 & $\mathrm{~T}$ & OxA-19878 & $5730 \pm 33$ & bone human & $\left(\sigma^{\prime}\right) 25+$ yrs, supine & $\mathrm{T}$ & (3) \\
\hline 87 & $T$ & OxA-24O42 & $5690 \pm 31$ & bone human & (\$) $12-18 \mathrm{yrs}$, posture unclear & $T$ & (3) \\
\hline 89 & $\mathrm{~F}$ & OxA-23618 & $5655 \pm 32$ & bone human & & $\mathrm{F}$ & (3) \\
\hline 94 & $\mathrm{~F}$ & OxA-13250 & $5626 \pm 31$ & bone human & sex unclear $20-40$ yrs, supine & $\mathrm{F}$ & $(1)$ \\
\hline 111 & $T$ & $\begin{array}{l}\text { OxA-13865 } \\
\text { OxA-13846 } \\
\text { OxA-18576 }\end{array}$ & $\begin{array}{l}5855 \pm 34 \\
5757 \pm 34 \\
5710 \pm 33\end{array}$ & $\begin{array}{l}\text { bone human } \\
\text { bone animal } \\
\text { antler animal }\end{array}$ & $\begin{array}{l}\sigma^{\prime} 20-60 \text { yrs, supine (and bones } \\
\text { of a not archaeologically recorded } \\
\text { second individual: }\left[\left[\sigma^{\prime}\right]\right] 16+\text { yrs) }\end{array}$ & $\begin{array}{l}\text { T: } N=2 \text { OxA-13846 and } \\
\text { OxA-18576, } \mu=5733(24) \\
\text { BP, } p=32 \%\end{array}$ & $\begin{array}{l}(1) \\
(1) \\
(3)\end{array}$ \\
\hline 112 & $T$ & OxA-13251 & $5702 \pm 32$ & bone human & sex unclear, $25-35$ yrs, supine & $T$ & $(1)$ \\
\hline
\end{tabular}




\begin{tabular}{|c|c|c|c|c|c|c|c|}
\hline Grave & CA & LabCode & $\begin{array}{l}\text { 14C-Age } \\
\text { [BP] }\end{array}$ & Material & Burial Type & $\begin{array}{l}\text { Radiocarbon } \\
\text { Model }\end{array}$ & Ref \\
\hline 117 & $T$ & $\begin{array}{l}\text { OxA-13848 } \\
\text { OxA-13811 }\end{array}$ & $\begin{array}{l}5766 \pm 36 \\
5530 \pm 36\end{array}$ & $\begin{array}{l}\text { bone human } \\
\text { bone animal }\end{array}$ & $\begin{array}{l}0 \times 35-55 \text { yrs, crouched left on } \\
\text { the chest (and bones of a not } \\
\text { archaeologically recorded } \\
\text { second individual: }\left[\left[{ }^{\circ}\right]\right] 20+y r s \text { ) }\end{array}$ & T: OxA-13848 & $(1)$ \\
\hline 121 & $F$ & $\begin{array}{l}\text { OxA-13252 } \\
\text { OxA-23619 }\end{array}$ & $\begin{array}{l}5672 \pm 34 \\
5771 \pm 31\end{array}$ & $\begin{array}{l}\text { bone human } \\
\text { bone human }\end{array}$ & ơ 50+, crouched right & $\mathrm{F}$ & $\begin{array}{l}\text { (1) } \\
\text { (3) }\end{array}$ \\
\hline 125 & $\mathrm{~T}$ & OxA-13253 & $5685 \pm 33$ & bone human & sex \& age unclear, supine & $\mathrm{T}$ & (1) \\
\hline 126 & $\mathrm{~T}$ & OxA-19879 & $5678 \pm 34$ & bone human & (o) $20+y r s$, supine & $T$ & (3) \\
\hline 127 & $\mathrm{~T}$ & OxA-24041 & $5735 \pm 31$ & bone human & $\sigma^{\prime \prime} 25-35$ yrs, supine & $T$ & (3) \\
\hline 129 & $\mathrm{~T}$ & OxA-19880 & $5728 \pm 34$ & bone human & (\$) $16 \pm 2$ yrs, posture unclear & $T$ & (3) \\
\hline 137 & $\mathrm{~T}$ & OxA-13694 & $5654 \pm 36$ & bone human & sex $\&$ age unclear, supine & $T$ & $(1)$ \\
\hline 139 & $\mathrm{~T}$ & OxA-23620 & $5668 \pm 33$ & bone human & (o') 50-60 yrs, posture unclear & $\mathrm{F}$ & (3) \\
\hline 143 & $\mathrm{~T}$ & \begin{tabular}{|c|} 
OxA-13689 \\
OxA-X-225643 \\
OxA-13690 \\
OxA-X-225831
\end{tabular} & $\begin{array}{l}5690 \pm 32 \\
5725 \pm 45 \\
5700 \pm 30 \\
5703 \pm 36\end{array}$ & $\begin{array}{l}\text { bone human } \\
\text { antler animal } \\
\text { bone animal } \\
\text { antler animal }\end{array}$ & o" 30-40 yrs, supine & $\begin{array}{l}\mathrm{T}: \mathrm{N}=4 \text { OxA-13689, OxA- } \\
\mathrm{X}-225643, \mathrm{OxA}-13690 \\
\text { and OxA-X-225831, } \mu= \\
5701 \text { (17) BP, } \mathrm{p}=94 \%\end{array}$ & $\begin{array}{l}\text { (1) } \\
\text { (3) }\end{array}$ \\
\hline 151 & $\mathrm{~T}$ & OxA-19931 & $5715 \pm 55$ & bone human & ơ $22 \pm 3$ yrs, supine & $\mathrm{T}$ & (3) \\
\hline 154 & $\mathrm{~T}$ & OxA-19930 & $5665 \pm 39$ & bone human & $\begin{array}{l}\left.\text { ( }{ }^{\circ}\right) 21 \pm 3 \text { yrs, crouched right } \\
\text { (and bones of a not archaeo- } \\
\text { logically recorded second } \\
\text { individual: } \sigma^{\circ} 50+\text { yrs) }\end{array}$ & $T$ & (3) \\
\hline 158 & $\mathrm{~T}$ & OxA-13688 & $5787 \pm 30$ & bone human & () $5,5-6,5$ yrs, crouched right & $\mathrm{T}$ & $(1)$ \\
\hline & $\mathrm{T}$ & MAMS-30944 & $5755 \pm 24$ & tooth human & & $\mathrm{F}$ & (4) \\
\hline 167 & $\mathrm{~T}$ & MAMS-15097 & $5508 \pm 27$ & bone human & sex unclear $13+$ yrs, crouched right & $T$ & (2) \\
\hline 171 & $\mathrm{~T}$ & OxA-19923 & $5666 \pm 37$ & bone human & sex \& age unclear, crouched right & $\mathrm{T}$ & (3) \\
\hline 174 & $\mathrm{~T}$ & OxA-23621 & $5658 \pm 32$ & bone human & $\sigma^{\prime} 40 \pm 5$ yrs, posture unclear & $\mathrm{F}$ & (3) \\
\hline 179 & $\mathrm{~T}$ & OxA-19924 & $5696 \pm 37$ & bone human & sex unclear $7-8$ yrs, crouched right & $T$ & (3) \\
\hline 182 & $\mathrm{~T}$ & $\begin{array}{l}\text { OxA-225644 } \\
\text { OxA-23622 }\end{array}$ & $\begin{array}{l}5610 \pm 45 \\
5659 \pm 31\end{array}$ & $\begin{array}{l}\text { antler animal } \\
\text { bone human }\end{array}$ & ơ $50+$ yrs, supine & T: OxA-225644 & (3) \\
\hline 197 & $\mathrm{~T}$ & OxA-19925 & $5689 \pm 38$ & bone human & $955+$ yrs, posture unclear & $\mathrm{T}$ & (3) \\
\hline 209 & $\mathrm{~T}$ & Poz-71452 & $5420 \pm 35$ & bone human & $\sigma^{\prime} 20+$ yrs, supine & $T$ & $(2)$ \\
\hline 215 & $\mathrm{~T}$ & OxA-13691 & $5668 \pm 32$ & bone human & $\begin{array}{l}\left(\sigma^{\prime}\right) 18-25 \text { yrs, supine (and bones } \\
\text { of a not archaeologically recorded } \\
\left.\text { second individual: [ } \sigma^{\prime}\right] 60+\text { yrs) }\end{array}$ & $T$ & (1) \\
\hline 225 & $\mathrm{~F}$ & OxA-13693 & $5660 \pm 29$ & bone human & sex unclear $12-15$ yrs, supine & $\mathrm{F}$ & (1) \\
\hline 249 & $\mathrm{~T}$ & OxA-19926 & $5618 \pm 39$ & bone human & $\sigma^{\prime} 40-55$ yrs, supine & $T$ & (3) \\
\hline 255 & $\mathrm{~T}$ & OxA-13254 & $5732 \pm 33$ & bone human & ơ $18-25$ yrs, supine & $T$ & $(1)$ \\
\hline 256 & $\mathrm{~T}$ & OxA-19927 & $5702 \pm 39$ & bone human & $\left(\left(0^{\prime}\right)\right) 40+$ yrs, supine & $T$ & (3) \\
\hline 261 & $\mathrm{~T}$ & OxA-24043 & $5539 \pm 32$ & bone human & o" 50-60 yrs, supine & $\mathrm{F}$ & (3) \\
\hline 286 & $\mathrm{~T}$ & $\begin{array}{c}\text { OxA-18577 } \\
\text { OxA-X-225645 } \\
\text { OxA-23623 } \\
\text { OxA-23624 } \\
\text { OxA-23625 }\end{array}$ & $\begin{array}{l}5564 \pm 30 \\
5555 \pm 45 \\
5688 \pm 32 \\
5654 \pm 31 \\
5646 \pm 31\end{array}$ & $\begin{array}{l}\text { bone animal } \\
\text { antler animal } \\
\text { bone human } \\
\text { bone human } \\
\text { bone human }\end{array}$ & $\begin{array}{l}((+)) 17-25 \text { yrs, supine (and bones } \\
\text { of a not archaeologically recorded } \\
\text { second individual: sex unclear } \\
17+\text { yrs) }\end{array}$ & $\begin{array}{l}\mathrm{T}: \mathrm{N}=2 \mathrm{OxA}-18577 \\
\text { and OxA-X-22645, } \\
\mu=5561(25) \mathrm{BP} \\
\mathrm{p}=87 \%\end{array}$ & (3) \\
\hline 288 & $\mathrm{~T}$ & MAMS-15098 & $5472 \pm 28$ & bone human & $\sigma^{\prime \prime} 55+y r s$, supine on the right & $\mathrm{F}$ & $(2)$ \\
\hline 293 & $\mathrm{~T}$ & OxA-X-225646 & $5725 \pm 40$ & bone animal & o $25-50$ yrs, supine on the left & $T$ & (3) \\
\hline 294 & $\mathrm{~T}$ & $\begin{array}{c}\text { OxA-X-225647 } \\
\text { OxA-23626 }\end{array}$ & $\begin{array}{l}5860 \pm 60 \\
5608 \pm 32\end{array}$ & $\begin{array}{l}\text { antler animal } \\
\text { bone human }\end{array}$ & ó $20-40$ yrs, supine & $\mathrm{F}$ & (3) \\
\hline
\end{tabular}

References: (1) Higham et al. 2007; (2) Krauß et al. 2014; (3) Higham et al. 2017; (4) Mathieson et al. 2017; (5) this study

\section{back to contents}

